VERTAISARVIOITU

KOLLEGIALT GRANSKAD

PEER-REVIEWED

www.tsv.fi/tunnus

\title{
KESKUSTELIJOIDEN YKSILÖLLISET EROT SUOMENKIELISEN VERKKOKESKUSTELUN ROMANIKIELISTEN SANOJEN KÄYTÖSSÄ
}

\author{
Mirkka Salo, Helsingin yliopisto
}

\begin{abstract}
Tarkastelen tässä tutkimuksessa kymmenen nimimerkin kielenkäyttöä suomenkielisellä internetin keskustelupalstalla suomi24.fi-romano. Metodina on yksilömurteita vertaileva variaationtutkimus. Olen kerännyt tutkimukseen kymmenen nimimerkin kaikki viestit ajalta 22.2.2003-18.7.2013. suomi24.firomano on tämän tutkimuksen valmistumisen aikana ainoa erityisesti Suomen romaneille tarkoitettu keskustelupalsta internetissä. Keskustelupalsta on suunnattu romanien väliseen keskusteluun. Keskustelufoorumin pääkieli on suomi, mutta monet keskustelijat käyttävät suomen varieteettia, joka sisältää romanikielisiä tai romanikieleen pohjautuvia sanoja, romanikielisiä rakenteita tai lauseita. Tutkin tällaisia viestejä. Tarkasteltavana ovat kunkin nimimerkin käyttämät romanikieliset elementit (lekseemit ja rakenteet), niiden määrä, sanaluokat, morfologia ja taivutus sekä käyttötehtävät.

Osa nimimerkeistä käyttää vain substantiiveja, osa laajemmin eri sanaluokkiin kuuluvia lekseemejä. Yhteinen piirre kirjoittajilla on romanikielisen elementin käyttö romani-identiteetin tai Suomen romanikulttuuriin liittyvän asian ilmaisemisessa. Kirjoittajien väliset erot romanikielen taivutuksessa ja kirjoitusasuissa voivat johtua taivutetun romanikielen käytön harvinaistumisesta. Nimimerkit eivät korjaa toistensa romanikielen taivutusrakenteita tai kirjoitusasuja. Kirjoittajien yksilömurteet eroavat eniten romanikielisen sanaston määrässä, mutta eroa on myös kieliopillisten rakenteiden määrässä ja monipuolisuudessa.
\end{abstract}

Avainsanat: etnolekti, idiolekti, romani, suomi, variaatio, verkkokeskustelu

\section{JOHDANTO}

\subsection{Tutkimusaibe}

Tässä tutkimuksessa tarkastellaan yksilöllistä vaihtelua romaneille tarkoitetun verkkokes-

Kirjoittajan yhteystiedot:

Mirkka Salo

mirkka.salo@helsinki.fi kustelupalstan viesteissä. Tarkoituksena on romanikielisten elementtien käytössä ilmenevien erojen lisäksi havainnoida, vahvistuvatko samasta aineistosta tehtyjen aiempien tutkimusten väitteet vai onko niistä tehtävä tarkennettuja päätelmiä.

Tarkastelen kymmenen nimimerkin kielenkäyttöä suomenkielisellä internetin keskustelupalstalla suomi24.fi-romano. Olen valinnut aineistokseni nimimerkkejä, jotka ovat kirjoittaneet kymmenen tai useampia 
suomenkielisiä viestejä ja käyttävät vähintään yhtä romanikielistä elementtiä näissä viesteissään. Romanikielisillä elementeillä tarkoitan romanikielisiä sanoja ja kieliopillisia rakenteita sekä romanikieleen pohjautuvia suomenkielisiä sanoja. Sisällytän termiin myös koodinvaihdon suomesta romanikielelle. Koodinvaihto on kielen vaihtamista puhuttaessa tai kirjoitettaessa (esim. Auer 1998). Käytän tässä tutkimuksessa samaa termiä myös vaihtelusta kielten välillä termin koodinvaibtelu sijasta. Näin termi koodinvaibto tarkoittaa tässä tutkimuksessa myös kielen vaihtoa yksittäisten sanojen kohdalla. Termiä pitkien jaksojen koodinvaihto käytän merkitsemässä kielen vaihtamista toiseksi paria sanaa pitemmän jakson ajaksi.

Vertailen romanikielisten elementtien käytön yksilöllisiä eroja tarkasteluun valitsemieni nimimerkkien välillä. Tarkasteltavana ovat kunkin nimimerkin käyttämät romanikieliset elementit (lekseemit ja rakenteet), niiden määrä, sanaluokat, morfologia ja taivutus sekä käyttötehtävät. Näiden avulla saadaan tietoa siitä, missä määrin ja miten romanikielen tai romanikielisten ilmaisujen käyttö vaihtelee yksilöittäin ja millaista tietoa vaihtelu antaa romanikielen käytön laajuudesta. Tarkennan näin tietoa romanikielisten elementtien nykyisestä käytöstä Suomen romanien suomen kielessä ja niiden käyttötavoista diskurssissa sekä laajennan kielenkäytön tutkimusta kirjoitetussa, digitaalisessa keskusteluympäristössä. Tarkastelen romanikielisten elementtien käyttöä eri kirjoittajien suomen kielessä suhteessa siihen, kirjoittavatko he kokonaan romanikielisiä lauseita tai sitä pitempiä jaksoja. Sen avulla voi tehdä havaintoja taivutetun romanikielen käytön mahdollisesta vaikutuksesta saman kirjoittajan suomen kieleen. Tutkimuksen tavoitteena on myös valottaa sitä, mitkä romanikieliset elementit ovat säilyneet ilmaisun välineenä eri keskustelijoilla digitaalisessa, suomenkielisessä keskusteluympä- ristössä ja mitä syitä niiden säilymiselle voi tutkimusaineistoni perusteella olettaa olevan.

\subsection{Tutkimukseni sijoittuminen tutkimusperinteeseen}

Romanikieltä sisältävän suomen tutkimus kuuluu kielikontaktien aiheuttamien muutosten ja variaation tutkimukseen (kielikontakteista esim. Matras, 2009). Kielikontaktien merkitys kielen muutoksessa on sosiolingvistisen variaationtutkimuksen kiinnostuksen kohteena. Länsimaisessa tutkimuksessa alan pioneerina tunnetaan William Labov (mm. 1972). Suomalaista sosiolingvististä tutkimusta edustavat esimerkiksi Hanna Lappalainen, Kaarina Mononen, Heini Lehtonen, Anu Rouhikoski ja Katri Priiki. Variaatiolla tarkoitetaan kielitieteessä kielellisten yksiköiden alueellisiin, sosiaalisiin tai funktionaalisiin eroihin perustuvaa vaihtoehtoisuutta. Sosiolingvistiikan nk. kolmannessa aallossa kielen variaatiot alettiin nähdä kielellisinä käytänteinä, kun niitä aiemmin oli tarkasteltu sosiaalisen identiteetin ja sosiaalisten kategorioiden heijastumina (Bucholtz, 2010; Bucholtz \& Hall, 2005; Eckert, 2012, s. 93-94; Irvine, 2001). Kielelliset variaatiot nähtiin nyt kielenkäyttäjien valintana sijoittaa itsensä erilaisiin tilanteisiin. Variaation tutkiminen romanikieltä sisältävän suomen käyttäjillä antaa tietoa sen tehtävistä romanien diskurssissa (vrt. Salo, 2017). Variaationtutkimuksen avulla voi havainnoida, missä tilanteissa romanikieliset elementit otetaan käyttöön suomenkielisessä keskustelussa.

Vuorovaikutussosiolingvistiikassa (interactional sociolinguistics) tarkastellaan kielellistä vaihtelua sosiaalisen kanssakäymisen osana. Puhujien - tai kirjoittavien keskustelijoiden - käsitykset ja sosiaaliset tulkinnat variaation merkityksistä näkyvät kielellisessä vuorovaikutuksessa (Gumperz, 1992, s. 50). Keskeistä on se, mitä vaihtelulla tehdään (Gumperz, 
2001, s. 218-223). Tulkittaessa variaation merkityksiä sosiaalisessa vuorovaikutuksessa on tarkasteltava myös puhujien omia tulkintoja ja näkemyksiä (Gumperz, 1992, s. 50). Ilmiön tarkastelu on keskeistä myös tässä tutkimuksessa. 1980-luvulta alkaen vuorovaikutuksen tutkimuksen painotus Suomessa on ollut etnometodologisessa keskustelunanalyysissa (ks. Nuolijärvi \& Sorjonen, 2005, 14; metodista Sidnell \& Stivers, 2012; ks. myös Auer, 1998). Suomalaisen tutkimuksen tarkastelun kohteena on usein ollut jonkin kielellisen tai ei-kielellisen keinon käyttö (esim. Haakana, 1999; Routarinne, 2003; Seppänen, 1998; Sorjonen, 2001) sekä joidenkin kielellisten toimintojen rakentuminen (esim. Berg, 2003; Halonen, 2002; Kajanne, 2001; Kangasharju, 1998; Lehtinen, 2002; Raevaara, 2000). Tutkimukseni on jatkoa tälle perinteelle, sillä keskityn tutkimuksessani romanikielen elementteihin ja niiden funktioihin.

Vuorovaikutuksen tutkimus on syventänyt käsitystä kielen käytön kontekstisidonnaisuudesta (Nuolijärvi \& Sorjonen, 2005, s. 14). Auerin 2007 toimittaman artikkelikokoelman kirjoittajat havainnoivat, miten kielellisissä valinnoissa ei ole kyse pelkästään puhujan vaan myös muiden tilanteeseen osallistuvien identiteetin konstruoinnista (Auer, 2007). Romanien verkkokeskustelussa viestin lukijoiden identiteetin konstruoinnilla on tärkeä osa keskustelussa esiintyvän variaation kannalta - muille kuin romaneille suunnatut vastaukset ja tervehdykset eivät sisällä yleensä yhtään romanikieltä. Gumperzin (2001, s. 218-223) mukaan puhujan valinnat ovat yhteydessä häntä ympäröivään sosiaaliseen todellisuuteen ja keskustelun rakentumiseen. Tämä on selvästi havaittavissa romanien keskustelussa niin puheenaiheiden kuin sanavalintojen ja muiden kielellisten valintojen kohdalla. Suomen romanien todellisuutta ovat muusta väestöstä erottuvaan, pieneen ja epäluulojenkin alaiseen ryhmään kuulumi- nen, voimakas oma kulttuurinen koodisto sekä yksilölliset haasteet siinä, mihin ryhmään identifioitua ja sijoittua.

Myös idiolekteja eli yksilömurteita on tarkasteltu suomalaisessa tutkimuksessa (esim. Mustanoja, 2011; Nahkola \& Saanilahti, 2001, s. 142-192; Nuolijärvi, 1986, s. 223-323; Palander, 1996). Idiolekti on henkilön oma kielimuoto (ks. Paunonen, 2005). Yksilömurteita esiintyy esimerkiksi välimurrealueilla, eli seuduilla, joissa murrepiirteet limittyvät (Palander, 1996). Myös muut kuin alueelliset seikat, esimerkiksi henkilön vanheneminen, voivat vaikuttaa ja tuoda muutoksia yksilön idiolektiin (vrt. Mustanoja, 2011). Yksilömurteen sisäisellä vaihtelulla, esimerkiksi svaan käytöllä vain toisinaan, voidaan hyödyntää tilanteenmukaista rekisterien vaihtelua (Nahkola \& Saanilahti, 2001).

Etnolekti on etniselle ryhmälle tietyllä alueella muodostunut oma kielimuoto. Suomen romanien etnolektilla tarkoitan romanikieltä sisältävää suomea. Romanien etnolekti (Salo, 2016, 2017) kielenä, jolla ei ole standardia ja jonka käyttäjien puheessa tai kirjoituksessa on variaatiota niin suomen (esim. suomen alueelliset murrepiirteet ja yleiskielen vs. puhekielen käyttö) kuin romanikielen kirjoitusasussa ja taivutuksessa mahdollistaa suurenkin yksilömurteiden vaihtelun. Tämä tutkimus tuo uuden keskustelevan ryhmän tarkasteltavaksi näiden teorioiden valossa ja laajentaa näin tuntemusta verkkokeskustelusta, vähemmistöjen kielistä ja keskustelusta sekä etnolekteista ja Suomen romaneista.

Vaikka tämä tutkimus tarkastelee yksilöllisiä eroja, samalla tulee esiin kielellisten keinojen käyttö ryhmäidentiteetin ilmaisijana ja yhteisöllisten normien säätelyssä. Vaattovaara (2009) tekee huomioita vaihtelevista yksilömurteisista eroista oman kielialueen murteen käytössä ja hyperdialektologisista muodoista nuorten puhumassa meänkielessä. Tutkimusaineistoni romanit käyttävät samoin yksilö- 
murteisia ilmaisuja pyrkimättä samanlaisuuteen keskustelukumppaniensa kanssa sanojen taivutuksessa ja kirjoitusasussa. Ainakin yksi vertailuni nimimerkeistä käyttää hyperkorrektia muotoa muodostaessaan romanikielistä lausetta. Suomenkielisessä lauseessa hän taivuttaa saman kieliopillisen muodon eri tavalla.

Suomen Romanien käyttämien kielten tutkimuksen aineistona on aiemmin käytetty muun muassa romanikielisiä tekstejä (Pirttisaari, 2003, 2004), Kotimaisten kielten keskuksen nauhoitteita Suomen romanikielen puhujilta (Kovanen, 2013a, 2013b) sekä tutkijan itsensä tekemiä haastatteluja ja hänen omia havaintojaan (Hedman, 2004, 2009). Hedman on tehnyt havaintoja romanikielen käytön vähenemisestä ja taidon heikkenemisestä sekä tutkinut sen syitä (Hedman, 2009, esim. s. 54-55). Oman tutkimukseni aineistona ovat verkkokeskustelut. Androutsopoulos (mm. 2013, 2006) on tutkinut monikielisyyttä, koodinvaihtoa ja etnisyys- ja identiteettitekijöitä sähköisessä viestinnässä sosiolingvistiseltä näkökannalta. Androutsopoulos (2013, s. 667) toteaa, että koodinvaihto (code-switching) ja koodien sekoittaminen (code-mixing) ovat yleisiä kielellisiä keinoja kaksi-ja monikielisillä puhujilla ja ne siirtyvät heillä helposti keskusteluun myös digitaalisessa medioissa (ks. myös Karppinen, 2011).

Salo $(2016,2017)$ on havainnut romanikielisten ja romanikieleen pohjautuvien sanojen ja ilmaisujen olevan verkkokeskustelussa lukumääräisesti vähäisiä mutta tarpeellisia diskurssifunktioidensa vuoksi. Diskurssifunktiolla tarkoitan (tässä tapauksessa romanikielisen) sanan ilmaisun tehtävää keskustelussa. Niiden käytön pohjalta Suomen romanikielen voi katsoa yhä vitaaliseksi käyttökieleksi, joka ei ole korvautunut pararomanilla. Tutkimuksissa tulee esiin myös suomen ja romanikielen yhdisteleminen uusien yhdyssanojen ja johdosten muodostamisessa. Tutkimukseni osoittavat, että verkkokeskustelussa käytetään romanikielisistä lekseemeistä eniten etnisyyttä ilmaisevia sanoja akselilla romani<>muu kuin romani. Käytettyjen lekseemien valtaosa on etymologialtaan varhaista intialaista alkuperää. Substantiivit ovat yleisimmin käytetty sanaluokka, sen jälkeen adjektiivit ja verbit. Käsillä oleva tutkimus tarkastelee samojen tutkimusmetodien pohjalta yksilömurteiden romanikielisten elementtien kvalitatiivisia, kvantitatiivisia ja diskurssifunktio-ominaisuuksia.

\subsection{Aiempaa tutkimusta suomen kielen ja} Suomen romanikielen subteesta

Suomen romanien ykköskieli on nykyään suomi (Granqvist, 2013, s. 104; Hedman, 2009, s. 23). Ruotsissa asuvat Suomen romanit puhuvat parhaiten suomea tai ruotsia (Granqvist, 2013, 104). Hedman (2009, s. $18,23)$ osoittaa tutkimuksessaan, että romani oli hänen haastattelemiensa 306 eri-ikäisen romanin seuraavaksi vahvin kieli vuonna 2009. Hedmanin tutkimuksen haastatelluista 262 asuu Suomessa ja 44 Ruotsissa. Vieraista kielistä romanit osaavat keskimäärin parhaiten englantia ja ruotsia (mt.), samoin kuin muut suomalaiset (Special Eurobarometer 386 - Europeans and their languages vuodelta 2012).

Romanikieltä Suomen vähemmistökielenä on esitelty ja tarkasteltu erilaisissa kotimaisissa ja kansainvälisissä yhteyksissä (esim. Vuorela \& Borin, 1998). Yleisen kielitieteen alalla on ilmestynyt tutkimusta suomen morfologisesta ja fonologisesta vaikutuksesta romanikieleen (Granqvist, 2007, 2012; Granqvist \& Pirttisaari, 2003; Pirttisaari, 2003, 2004) ja romanikielen attritiosta eli rapautumisesta (Granqvist, 2013). Suomen vaikutusta näkyy esimerkiksi perfektin ja pluskvamperfektin muodostuksessa ja äänteiden suomalaistumisessa. Äänteiden suomalaistuminen on yleis- 
tä yksilömurteissa ja Suomen romanikielen itämurteessa, joka on Suomen romanikielen puhutuin murre. Romanikielen attritio ilmenee sekä idiolektistumisena että romanikielen käytön korvautumisena romanikieltä sisältävällä suomella (viimeksi mainitusta on julkaissut artikkelin myös Åkerlund, 2004). Koodinvaihtoa Suomen romanikielen ja suomen välillä on tutkinut Kovanen (2013a, 2013b), ja koodinvaihtotilanteiden kulttuurisia syitä Granqvist ja Viljanen (2002). Hedman $(2004,2009)$ on julkaissut tutkimuksia romanien kieliasenteista ja romanikielen nykyisestä asemasta yhteisössään. Hän tuo esiin tietoa myös yleisimmistä tilanteista, joissa Suomen romanit käyttävät romanikieltä esimerkiksi kotipiirissään. Romanikielisten lainasanojen ja koodinvaihdon tehtäviä Suomen romanien verkkokeskustelussa on tutkinut Salo (2016). Tutkimuksessa tarkastellaan verkkokeskusteluaineistoa kokonaisuutena ja tehdään yleispäätelmiä romanikielisten sanojen käyttötehtävistä. Myös tässä tutkimuksessa tarkastellaan käyttötehtäviä, mutta kirjoittajien kielessä esiintyvien yksilöllisten erojen näkökulmasta. Yhteisiä havaintoja tässä ja Kovasen, Granqvistin ja Viljasen sekä Hedmanin mainituissa tutkimuksissa ovat romanien häveliäisyys- ja puhtaussäännöt ja salakielikäyttö koodinvaihdon syinä.

Romanikielen sanasto on tätä kirjoittaessani yhä suurimmaksi osaksi tuntematonta muille Suomen etnisille ryhmille. ${ }^{1}$ Toista ympäristössään vähälukuisten puhujien käyttämää kieltä, Inkerinmaalla ja Virossa puhuttavaa inkerinsuomea tutkinut Kokko (2007a, 2007b) esittää rapautumisilmiöistä seuraavia havaintoja: kielessä esiintyy kontrolloimaton-

\footnotetext{
1 Romanikieli on vuodesta 2012 alkaen ollut yliopistollinen oppiaine Helsingin yliopistossa, ja sen käyttö virallisten verkkosivujen kielenä on lisääntynyt varsinkin 2010-luvulla. Nämä muutokset tulevat todennäköisesti lisäämään yleistä tietoa romanikielestä.
}

ta vaihtelua, kielen idiolektistumista ja attritiota kielenvaihdon ja muiden, dominoivien kielten vaikutuksen vuoksi (mts., 31-45). Kumpikin kielimuoto on vähemmistökielenä alueellaan pieni, vaikka Euroopan laajuisesti puhuttuna yleisempi, kun otetaan huomioon myös kielen toiset murteet. Tutkimukseni avulla voi verrata Suomen romanien käyttämien kielimuotojen tilannetta näihin rapautumisilmiöihin. Inkerinsuomen puhujien mahdollisuus käyttää alkuperäistä äidinkieltään Inkerinmaalla ja Virossa on rajoittunut oman etnisen ja kulttuurisen yhteisön piiriin, kuten on pitkään ollut Suomen romanikielen puhujien kohdalla. Myös Inkerinsuomi on alun perin maahanmuuttajien kieltä (Kokko 2007 b, s. 1). Inkerinsuomi luetaan suomen kaakkoismurteisiin, mutta sen puhujien asuinalue ei ole kuulunut Suomen valtion alueeseen (mt.). Yhteistä näille kielille on myös se, että kummankin kielen kontaktit enemmistökieleen näkyvät kahden eri kielen elementteinä puheessa.

\subsection{Aineisto ja menetelmät}

Tutkimusaineistona on keräämäni Internetin keskustelupalstan Suomi24.fi-romano koko arkisto ajalta 22.2.2003-18.7.2013. Aineisto on laajuudeltaan suuri, 1753538 sanaa, joista olen laskenut romanikieliset ja romanikieleen perustuvat lekseemit niiden kvantitatiivista ja etymologista vertailua varten (Salo 2015, 2016, 2017). Löysin romaniin pohjautuvia lekseemejä 188 kappaletta. Jos romanikielisten sanojen käyttöyhteys ja viestien muu sisältö vaikutti vahvasti kertovan romanikirjoittajasta, kirjoittaja valikoitui vertailuun. Koska minulla ei ollut mahdollisuutta kysyä kaikkien lainaamieni nimimerkkien suostumusta viestien tutkimuskäyttöön, pyrin kirjoittajien mahdollisimman tarkkaan anonyymisointiin. Heidän sekä keskustelun kohteena olevien henkilöiden anonymiteetin suojelemiseksi 
olen vaihtanut julkaisemiini lainauksiin nimet kirjaimiksi, lukuun ottamatta presidenttiehdokasta, jota koskeva tieto on julkista tietoa.

Tämä on osatutkimus romanikielisten elementtien ja koodinvaihdon käytön tutkimustani Suomen romanien suomenkielisessä verkkokeskustelussa. Olen havainnut kirjoittajien välillä eroja romanikielisten sanojen käytössä, jopa yksilöllisiä idiolekteja, joka on vaikuttanut tämän osatutkimuksen syntyyn. Tässä osatutkimuksessa tarkastelen myös romanikielisiä lauseita vertailemillani nimimerkeillä, koska tarkoitukseni on vertailla romanikielisten elementtien käytössä esiintyviä eroja paitsi kirjoittajien välillä myös yksilömurteiden sisällä. Keräsin valitsemieni nimimerkkien kaikki viestit, luin ne ja etsin viesteistä romanikieliset sanat sekä niiden käyttöyhteydet. Tutkin vertailuun valikoituneiden nimimerkkien romanikielisten sanojen määrät, sanaluokat, ja taivutuksen. Tutkin myös romanikielisten jaksojen pituudet sekä romanikielisten sanojen tai pitempien jaksojen ja koodinvaihdon diskurssifunktiot eli käyttötehtävät keskustelussa. Käyttötehtäviä ovat esimerkiksi etnisen identiteetin ilmaiseminen, viestin salaaminen osalta kuulijoista käyttämällä toisen kielen ilmaisua ja häveliäisyyssääntöjen huomioiminen (vrt. Salo, 2016). Koodinvaihtelu on tiheää silloin, kun kirjoittajan on täydennettävä romanikielisiä jaksoja suomen kielellä (vrt. esim. Kovanen, 2013b). Diskurssifunktioiden tunnistamisessa on apuna romanikielen tuntemus ja lisäksi romanikielestä ja siinä esiintyvästä koodinvaihdosta sekä romanikulttuurista tehty aiempi tutkimus. Tutkin romanikielisten sanojen ja rakenteiden käytön diskurssifunktioita tarkastelemalla niiden käyttötilanteita keskustelun kontekstissa (vrt. Salo, 2016). Tässä artikkelissa vertaan diskurssifunktioita kymmenellä eri kirjoittajalla.

Suomi24.fi on suomenkielinen, epäviralli- nen ja asynkroninen eli eriaikainen keskustelufoorumi (ks. Salo, 2016, s. 254). Aineistossa on myös kokonaan romanikielisiä viestejä, tosin kokonaismäärään verrattuna vähän. Keskustelupalsta on suunnattu romanien väliseen keskusteluun (http://keskustelu. suomi24.fi/ryhmat/romano). Viestien sisällöistä ja nimimerkeistä päätellen palstalle kirjoittaa alkuperältään Suomen romaneja maantieteellisesti laajalta alueelta, myös Ruotsista. Suomen perinteistä romanivähemmistöä (kaale) asuu koko maan alueella, vähiten pohjoisimmassa Lapissa (Hedman 2009 , s. 20). Ruotsissa asuu arviolta 30004000 Suomen romania (Laiti, 2008, s. 156). Aineistosta ei ole aiemmin tutkittu kirjoittajien yksilöllistä romanikielisten elementtien käyttöä, kun kirjoituksen pääkielenä on suomi. Tutkimukseen valituilta nimimerkeiltä löytyy viestejä, joissa suomenkielisen lauseen osana on romanikieleen pohjautuva sana tai suomenkielisiä viestejä, joiden osana on romanikielisiä lauseita.

Suomen kielellä on vaikutusta Suomen romanikieleen pohjautuvien sanojen äänneasuun ja edelleen kirjoitusasuun. Osa kirjoitusasun ominaisuuksista johtunee myös teknisistä syistä, kuten romanikielen ortografian mukaisten kirjainten ( $̌$, ž ja ȟh) lisäämisen hidastavasta vaikutuksesta kirjoittamiseen. Tutkimusaineistossani äänteet kirjoitetaan suomalaiseen tapaan, esimerkiksi tsibko < tsihhko 'hyvä. Kirjoitusmuoto latz < latš-e 'kiltti-PL' saattaa todennäköisemmin olla suomalaisen näppäimistön tarjoamista kirjainvaihtoehdoista johtuva. Suomen romanikielestä ei ole muodostettu standardia. Koivisto (1994, 2001) käyttää romanikielen sanakirjoissaan omaa murrettaan, jonka mukainen kirjoitusasu ja ääntäminen on käytössä myös Helsingin yliopiston romanikielen opetuksessa. Suomen romanikielen eniten käytetty itämurteinen ääntäminen ja kirjoitusasu poikkeavat sanakirjoissa ja yliopiston oppikirjois- 
sa käytettävästä. Itämurteessa kirjoitusasu ja ääntäminen noudattavat suurin piirtein suomalaista aakkostoa. Äännevaihtelut $j / \mathrm{dž}, s / t \grave{s}$, ja $h / h$ esiintyvät Suomen romanien puheessa. Suomen puhekielen soinnillisten ja soinnittomien klusiilien $b / p, g / k$ ja $d / t$ vaihteleva käyttö ilmenee kirjoittajien yksilömurteissa (vrt. Granqvist, 2007, s. 69-75). Varsinkin $t$ $<d$ on vertailuaineistossani yleinen, Suomen romanikielen itämurteen mukainen muoto. Aineistossa se esiintyy esimerkiksi sanoissa tikk- < dikk- 'nähdä, katsoa' ja teulikaano < deulikaano 'uskovainen'. Sana deevel / Deevel 'jumala' esiintyy vertailun kirjoittajista G:llä muodossa teevel. Sanassa lupni < lubni 'huora' ja siitä muodostetussa verbissä lupnaavat (lupnata < lupnav- <lubnav-) näkyy muutos $b>p$. Suomen vaikutuksesta verbi on saanut myös pitkän vokaalin $a<\bar{a}$. Vertailun nimimerkit käyttävät suomen kielen vaikutusta olevaa soinnitonta klusiilia $k$ < $g$ sanoissa $k a a-$ ji / kääji < gaaji 'ei-romaninainen' ja kaajo < gaajo 'ei-romani, ei-romanimies'.

Keskustelupalstalla käytetään huomattavasti enemmän Suomen romanikielen itämurteen mukaisia kirjoitusasuja kuin muiden murrealueiden kirjoitusasuja, esimerkiksi muotoja jeeno 'mies, romanimies' ja juuli 'nainen, romaninainen' pro länsimurteen tšeeno ja tšuuli (murrepiirteistä kts. Granqvist, 2007, s. 64-65, 76-77). Koko laajassa aineistossa löytyy sanahaun avulla yksi esimerkki muodon djeeno käytöstä - se on romanikielisessä lauseessa, yksi muodon dzeeno käytöstä, neljä esimerkkiä muodosta $d z u u l i$ ja kerran esimerkki muodon djuuli käytöstä. ${ }^{3}$ Itämurteen muotoja käyttävät myös kaikki vertai-

2 Esimerkiksi Koiviston sanakirjoissa $(1994,2001)$ ja Helsingin yliopistossa käytössä olevissa oppimateriaa-

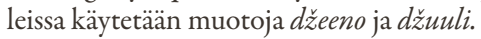

3 Word-muotoon muutetun aineiston 1753538:n sanan laajuudesta on mahdollista jäädä sanahaulla havaitsematta jokin esiintymä. 24.5.2010: kaalo dzeeno oot oikiassa. 6.2.2010: ... Ame fintiko phurano djeeno. 21.2.2012: "petollinen djuliskaa"... lun nimimerkit. Suomen murteiden käyttö on useilla keskustelijoilla vain osittaista; he käyttävät murteellista muotoa vain joissakin sanoissa. Täysin murteellisia lauseita on vähemmän. Valtaosa keskustelupalstan suomen kielestä on suomen yleiskieltä.

Tutkimuksessa vertailen kymmentä keskustelupalstalle paljon kirjoittavaa keskustelijaa, jotka käyttävät vakituista nimimerkkiä. Valitsin suomeksi kirjoittavia keskustelijoita, joiden viesteissä oli käytetty vähintään yhtä romanikielistä sanaa. Palstalla on julkaistu viestejä myös muilla kielillä. ${ }^{4}$ Määrittelen suomenkieliseksi keskusteluksi kielen, joka on kirjoitettu pääosin suomeksi. Aineistoni suomenkieliset keskustelut sisältävät myös muun kielisiä lauseita. Romanikieliseksi määrittelen lauseen, jonka verbit ovat romanikielen kieliopin mukaisia ja/tai joka on suurimmaksi osaksi kieliopilliselta rakenteeltaan romanikielinen. Esimerkiksi lauseessa Aabben nyt deevelessa kaikki!'Olkaa nyt Jumalan kanssa kaikki/Jumalan siunausta nyt kaikille' on romanikielinen verbi ja substantiivin instrumentaalimuoto, ja määrittelisin sen romanikieliseksi. Lauseessa Sinä olet siivengo kaaji 'Sinä olet ei-romani(vanhempi)en valkolaisnainen' on romanikielen monikon genetiivi, mutta käytän rajanvetona suomen kielen mukaan taivutettua verbiä ja laskisin sen suomenkieliseksi. Nominatiivimuoto kaaji on saman näköinen romanikielen ja suomen kieliopissa.

\subsection{Tutkimuksen nimimerkit ja aineiston tuottamat ongelmat ja rajoitukset}

Tässä luvussa esitellään tutkimukseen valitut nimimerkit. Tuon myös esiin aineistoni, anonyymin keskustelupalstan, tuottamia ongelmia ja rajoituksia. Kuvaan seuraavaksi

\footnotetext{
$4 \quad$ Palstalta löytyy esimerkiksi nimimerkki, joka julkaisee pitkiä viestejä useammalla eurooppalaisella kielellä. Nämä viestit vaikuttavat kopioiduilta muista lähteistä.
} 
nimimerkkien piirteitä välttäen täsmällisiä tuntomerkkejä anonyymiuden säilyttämiseksi. Osa nimimerkeistä sisältää erisnimiä, joista yksi on nykyään yleisempi Suomen romanien kuin muiden suomalaisten parissa. Neljässä nimimerkissä on vain suomenkielisiä sanoja, yhdessä vain romanikielisiä ja yhdessä suomen- ja romanikielinen sana. Yksi nimimerkeistä on muu kuin romani- tai suomenkielinen substantiivi. Suomen romanikieltä edustavia sanoja on nimimerkeissä yhteensä kaksi kappaletta. Niistä toinen esiintyy kahdessa eri nimimerkissä ja kahdessa erikielisessä rakenteessa: toinen romanikielisessä sanaliitossa ja toinen kaksikielisessä sanaliitossa. Näistä romanikielinen sanaliitto on ainoa kokonaan romanikielinen nimimerkki. Nimimerkkien joukossa on myös yhdyssana ja substantiivilauseke. Romanikielisiä sanoja, romania merkitseviä sanoja tai romaneille tyypillisiä nimiä sisältävien nimimerkkien käyttäjät luovat romani-identiteettiä jo nimimerkillään (vrt. Priiki, 2017, 19; De Fina ym., 2006; Eckert, 2000; Omoniyi ja White, 2006).

Nimimerkit on korvattu tässä artikkelissa kirjaimilla A-J tunnistettavuuden peittämiseksi. Kirjoittaja on lisännyt joitakin kertoja nimimerkkiin D aitoutta ilmaisevan sanan erotukseksi toisesta saman nimimerkin käyttäjästä. Mahdollinen toinen nimimerkin käyttäjä pyrkii alkuperäisen kanssa samaan tyyliin. D ilmoittaa joskus, että hänen nimellään on kirjoittanut viimeksi joku muu. Toisen kirjoittamiksi ilmoitettuja viestejä ei ole otettu mukaan vertailuun. H käyttää myös nimimerkkiä $\mathrm{H}$ ykkönen erotukseksi nimimerkeistä H kakkonen ja H kolmonen. Nimimerkkiä J käyttävä kirjoittaja kertoo viestissään olevansa eri kirjoittaja kuin samaa nimimerkkiä käyttävä toinen kirjoittaja. Alkuperäiset nimimerkit jakautuvat selkeästi kahteen sukupuoleen: A, B, D, E, G, H ja J ovat naiseen viittaavia nimimerkkejä, $C, F$ ja I mieheen viittaavia. Joukossa ei ole sukupuo- lineutraaleja nimimerkkejä. Nimimerkkien valinnassa en käyttänyt valintaperusteena sukupuolen esittämistä nimimerkissä. Kaikki vertailun kirjoittajat mainitsevat kuitenkin jossakin viestissään sukupuolen, joka vastaa nimimerkin antamaa mielikuvaa. Sukupuolivertailu on kuitenkin epävarmalla pohjalla verkkokeskustelun tutkimuksessa, koska viestien todellisesta kirjoittajasta ei voi olla täysin varma. Se on eräitä verkkokeskustelun tutkimuksen asettamia rajoituksia, kuten myös mahdollisuus vertailla kirjoittajien ikää. Nimimerkki B kertoo olevansa 19-vuotias ja nimimerkki C yli kuudenkymmenen ikäinen. Analysoituani vertailuun valittujen nimimerkkien kieltä havaitsin, että monipuolisinta romanikielisten elementtien - lekseemien ja rakenteiden - käyttöä esiintyy nimimerkeillä D ja I. D:n nimimerkki ja viestien sisältö viittaavat kirjoittajan naispuolisuuteen ja I:n miespuolisuuteen.

\section{VERTAILTUJEN VIESTIEN KVANTITATIIVISTA TARKASTELUA}

Tässä luvussa tarkastellaan kunkin kirjoittajan viestien määriä sekä romanikielisten ja suomenkielisten lekseemien määriä viesteissä, romanikielisten jaksojen pituutta ja romanikielisten sanojen sanaluokkia.

\subsection{Viestien määrät, sanamäärät ja sanojen käyttökerrat}

Taulukossa 1 esitetään nimimerkkien viestien määrät, sanamäärät ja suomenkielisten ja romanikielisten sanojen käyttökerrat. Osa kirjoittajista käyttää romanikielisiä sanoja luonnollisesti myös mainitessaan romanikielisiä elementtejä sisältävän nimimerkin. Niitä ei kuitenkaan lasketa tässä mukaan viestien romanikielisten sanojen määrään. 
Taulukko 1. Nimimerkkien viestien ja niissä olevien sanojen määrät ja prosentuaaliset osuudet

\begin{tabular}{|l|l|l|lc|lc|}
\hline Nimimerkki & Viestimäärä & Sanamäärä & Suomi & \multicolumn{2}{|l|}{ Romani } \\
\hline$A$ & 17 & 1106 & 1044 & $94,4 \%$ & 62 & $5,6 \%$ \\
\hline$B$ & 33 & 2844 & 2830 & $>99 \%$ & 14 & $<1 \%$ \\
\hline$C$ & 20 & 1118 & 1102 & $99 \%$ & 16 & $1 \%$ \\
\hline$D$ & 98 & 4323 & 4200 & $97,1 \%$ & 123 & $2,8 \%$ \\
\hline$E$ & 279 & 11821 & 11731 & $99 \%$ & 90 & $1 \%$ \\
\hline$F$ & 316 & 8181 & 8164 & $>99 \%$ & 19 & $<1 \%$ \\
\hline$G$ & 107 & 1410 & 1389 & $99 \%$ & 21 & $1 \%$ \\
\hline$H$ & 95 & 9573 & 9546 & $>99 \%$ & 27 & $<1 \%$ \\
\hline$I$ & 107 & 3364 & 3183 & $94,6 \%$ & 181 & $5,4 \%$ \\
\hline$J$ & 83 & 4278 & 4141 & $98 \%$ & 65 & $2 \%$ \\
\hline
\end{tabular}

Taulukko 1 osoittaa, että jokainen nimimerkeistä käyttää valtaosaltaan suomenkielisiä sanoja. Niitä on jokaisella kirjoittajalla yli tuhat, useimmilla useita tuhansia. Olen laskenut määriin myös useampaan kertaan samassa muodossa käytetyt lekseemit kummastakin kielestä. Romanikielisiä sanoja käyttävät määrällisesti eniten nimimerkit D ja I, joilla on yli sata romanikielisen sanan esiintymää. Myös prosentuaalisesti romanikielisten sanojen osuus on heillä suurimpien joukossa, I:Ilä $5,4 \%$ ja D:Ilä 2,8 \% heidän viestiensä sanojen yhteissanamäärästä. Prosentuaalisesti eniten romanikielisiä sanoja on A:lla, joka käyttää 62 kertaa romanikielistä sanaa, mikä on 5,6 \% tämän nimimerkin kokonaissanamäärästä. J:n viesteissä on 65 romanikielisen sanan esiintymää, $2 \%$ hänen kokonaissanamäärästään. Nimimerkit C, D, E ja I kirjoittavat myös kokonaisia romanikielisiä lauseita suomenkielisen keskustelun kehyksessä (E:llä yksi lause, muilla useampia). Romanikieltä kirjoittavilla C:Ilä ja E:llä romanikielisten sanojen prosentuaalinen osuus on vain $1 \%$ heidän viesteissään. Kuudella kymmenestä nimimerkistä romanikielisten sanojen pro- sentuaalinen osuus onkin korkeintaan 1\% viestien kokonaissanamäärästä, vaikka yhtenä tärkeimpänä perusteena valita heidät vertailuun on se, että heillä esiintyy romanikielisten sanojen käyttöä. Vertailun nimimerkeistä kahdella esiintyy suomenkielinen, mutta romanikulttuurin mukainen tai romanikielen mukaan muodostettu ilmaisu: nimimerkki I:n sanan "vanhemmat" välttely ja E:n tapa käyttää sanan asunto tai huoneisto sijasta sanaa buoneet, romanikielisen ilmaisutavan duituja 'huoneet' mukaisesti.

\subsection{Romanikielisten jaksojen pituus, lekseemimäärät ja taivutusmuodot suomenkielisissä lauseissa}

Taulukko 2 esittää ensimmäisessä sarakkeessa romanikielisten jaksojen pituuden suomenkielisissä lauseissa sanamäärittäin. Nimimerkkejä osoittavien kirjainten alle on merkitty, montako kertaa minkäkin pituinen jakso esiintyy kullakin nimimerkillä. Merkintä $>/=3$ tarkoittaa vähintään kolmen sanan pituista jaksoa ja merkintä $>5$ tarkoittaa enempää kuin viittä esiintymää. 
Taulukko 2. Romanikielisten jaksojen pituudet vertailun nimimerkeillä suomenkielisissä lauseissa. Merkintä $>5$ tarkoittaa viittä tai useampaa esiintymäkertaa.

\begin{tabular}{|l|l|l|l|l|l|l|l|l|l|l|}
\hline Jakson pituus & $\mathrm{A}$ & $\mathrm{B}$ & $\mathrm{C}$ & $\mathrm{D}$ & $\mathrm{E}$ & $\mathrm{F}$ & $\mathrm{G}$ & $\mathrm{H}$ & $\mathrm{I}$ & $\mathrm{J}$ \\
\hline 1 & $>5$ & $>5$ & 1 & $>5$ & $>5$ & $>5$ & $>5$ & 3 & $>5$ & $>5$ \\
\hline 2 & 1 & 0 & 0 & 1 & 1 & 2 & 0 & 2 & 3 & 0 \\
\hline$>/=3$ & 0 & 0 & 0 & 0 & 0 & 0 & 0 & 0 & 0 & 0 \\
\hline
\end{tabular}

Taulukosta 2 huomataan, että romanikieliset jaksot ovat suomenkielisissä jaksoissa kaikilla nimimerkeillä yleensä yhden sanan mittaisia suomenkielisissä lauseissa. C:llä on suomenkielisissä lauseissaan vain yksi yhden sanan pituinen romanikielinen jakso. Tämä jakso kuuluu samaan virkkeeseen, jossa on myös romanikielinen lause. Kellään nimimerkeistä ei ole kolmen tai useamman romanikielisen sanan jaksoa suomenkielisissä lauseissaan. Kahden sanan mittaisia jaksoja on nimimerkeistä kuudella. Kahden sanan pituiset jaksot sisältävät kaksisanaisen toivotuksen tai sanat kaalo ja/tai kaajo, kuten esimerkissä (1).

\section{(1)... sitä mieltä että romanit romaneille ja kaaj-eet kaaj-eille, ... (F) \\ ei-romani- ei-romani}

Taulukko 3 (ks. liite 1) esittää kunkin nimimerkin suomenkielisissä lauseissa esiintyvät romanikieliset lekseemit taivutusmuotoineen ja lekseemien käytön määrän. Lekseemien käyttömäärät on esitetty numeroilla taivutusmuotojen sarakkeissa.

Vertailuun ottamani nimimerkit käyttävät suomenkielisissä lauseissa yhteensä 31 romanikielistä lekseemiä. Arviot Suomen romanikielen leksikaalisten juurten kokonaismäärästä ovat 2000 ja 2600 välillä (Granqvist, 2007, s. 250). Taulukosta 3 näemme, että nimimerkit käyttävät muita romanikieleen pohjautuvia sanoja useimmiten vain yhden kerran, joitakin kaksi tai kolme kertaa, mutta puolet (5) nimimerkeistä käyttävät lekseemejä kaalo 'romani' ja kaajo 'muu kuin romani' lähes kahdestakymmenestä yli sataan kertaan. Nämä sanat ovat koko keskustelupalsta-aineistossakin selkeästi eniten käytetyt sanat (Salo, 2017, 2018). Näiden sanojen käyttömäärien eroina on mainittavaa myös, että C käyttää lekseemiä kaalo vain 3 kertaa, lekseemiä kaajo 2 kertaa ja lekseemiä kaaji / kääji kerran. C on yksi niistä nimimerkeistä, jotka kirjoittavat myös taivutettua romanikieltä. Myös F ja H käyttävät näitä kokonaisaineistossa yleisesti viljeltyjä romanikielisiä sanoja vähän. B:1lä esiintyy 14 kertaa lekseemi kaalo, mutta ei lekseemejä kaajo taikaaji / kääji. Yleisimpien romanikielisten lekseemien kirjoitusasussa on eroa jopa saman kirjoittajan viesteissä. A:lla, jonka viesteissä esiintyy 28 kertaa lekseemi kaalo ja 18 kertaa kaajo, lekseemi kaaji / kääji 'ei-romaninainen' on neljästi muodossa kaaji ja kerran muodossa kääji.

\subsection{Pitkät romanikieliset koodinvaibtojaksot}

Pitkillä koodinvaihtojaksoilla tarkoitan yli kahden sanan pituisia romanikielisiä jaksoja, kuten Granqvist (2000) tutkimuksissaan suomenkielisistä sanoista romanikielisessä puheessa. Myös Adamou ja Granqvist (2015) käyttävät samanlaista määrittelyä. Pitkiä ro- 
manikielisiä jaksoja on vertailun kirjoittajista C:llä, D:llä, E:llä ja I:llä. E:n pitempi jakso on yksi kokonaan romanikielinen lause. Taulukossa 4 (ks. liite 2) esitetään näiden kirjoittajien romanikielisissä jaksoissa käyttämät lekseemien taivutusmuodot ja käyttömäärät.

Taulukosta 4 huomataan, että C:n romanikielisen jakson kielioppi ja sanasto ovat virheettömiä, mutta leksikko vähälukuista verrattuna viestin suomenkieliseen osaan. D sen sijaan suorittaa useita pitkiä koodinvaihtoja viestissään ja vaihtelee koodia tiuhaan lyhyempien jaksojen kohdalla (esimerkki 2). Puhutteluna D käyttää sekä teitittelymuotoa tumen san 'te olette' että sinuttelua. D:n romanikielessä on sekä genetiivin, datiivin ja ablatiivin romanikielistä taivutusta että kielen muuttumisen merkkejä, kuten 3. persoonan mukaisen verbin taivutuksen korvautuminen yksikön 1. persoonan mukaisella taivutuksella, kuten seuraavassa esimerkissä. Tumen phenn-a esimerkin 3. rivillä on ilmaisu, jonka persoonapronomini on monikon 1. persoonan pronomini (1PL, teitittely), mutta verbi on yksikön 1. persoonan muodossa. 3 . persoonassa yksikkömuoto olisi phenn-el-a ja monikko phenn-en-a. Kirjoittajalla on myös yksinkertaistuneita muotoja, kuten datiivilla ilmaistavan $v$ - hojum-es-ke 'tulla vihaiseksi' korvaaminen nominatiivimuodolla $v$-hojume. Tässä myös subjekti siiva on ilmaistu monikon datiivimuodossa sivv-en-ge. Subjekti voisi esiintyä tässä ilmaisussa myös nominatiivimuodossa.

\section{(2) brmm nauraakaan me naa jaanav-a ${ }^{5}$ so tuu tenk-ill-a.}

nyt minä NEG tietää-PRS.1SG mitä sinä ajatella-PRS.2/3SG-IND

me aabh-a-a bortta kaal-en-go ju-j-ja.

minä olla-PRS.1SG-IND aito, oikea romani-OBL.PL-GEN nainen-välivok-PL

touvab-in sibkas tumen phenn-a $a^{6} \quad$ jakkes toola siiv-en-ge

tuo olla-PRS.3SG.IND hyvin te sanoa-PRS.1SG niin nuo ei-romani-OBL.PL-DAT

v-el-a bojume... sa-l-aaaaaaa.

tulla-PRS.3SG-IND vihainen nauraa-PRS.3SG-IND

nauraaaaaaaaaa yhtä älä tee, että kerrot niitten värit.

Me sa-l-a jakkebuut so merr v-el-a...

minä nauraa-PRS-3SG-IND niin paljon joka, jotta kuolema tulla-PRS.3SG-IND

nauraaaaa ...muuten minäkin ostin samanlaisen mersun mutta shampanja värisen.

Hyvää kesää sulle taad-os-ta. Tä̈lä hobiposkeero. nauraaaa

isä-OBL-ABL valehtelija

”... Nyt minä tiedän mitä sinä ajattelet. Minä olen aito romaninainen. Tuo on teiltä hyvin sanottu, niin nuo valkolaiset vihastuvat... nauran. Minä nauran niin paljon, että kuolen nauruun. ... Hyvää kesää sulle isältä(?). Täällä valehtelija. Nauraa.”

5 Taivutusmuodon jaanav-a indikatiivia ilmaiseva $a$ on sulautunut PRS.1SG:a ilmaisevaan $a$ :han.

6 Taivutusmuodon phenn-a-a indikatiivia ilmaiseva $a$ on sulautunut PRS.1SG:a ilmaisevaan $a$ :han. 
Nimimerkit, jotka kirjoittavat myös taivutetulla romanikielellä, käyttävät vertailun monipuolisinta romanikieltä. D käyttää romanikielisissä lauseissaan esimerkiksi verbistä $s-$ / b- 'olla' muotoja $b$-in (olla-PRS.3SG.IND) ja $s$-an (olla-PRS.2PL.IND) ja kirjoittaja I muotoja $h$-in (olla-PRS.3SG.IND) ja s-al (ollaPRS.2SG.IND). D käyttää neljää pronominia ja useampaa taivutusmuotoa: tuu 'sinä-NOM' sekä tu-ke 'sinä-DAT' ja I viittä eri pronominia, kun persoonapronominista me 'minä-NOM' erillinen genetiivi maro 'minun' lasketaan eri lekseemiksi. Joistakin pronomineista on useampi taivutusmuoto.

Kahdella runsaimmin romanikielisiä lauseita kirjoittavalla nimimerkillä (D ja I) on runsaammin sanaston ja taivutusmuotojen variaatiota myös suomenkielissä lauseissa muihin verrattuna. Kolmen muun romanikieltä kirjoittavan nimimerkin kohdalla asia ei ole näin. Taivutetun romanikielen käyttö ei siten aina erotu suomenkielisten lauseiden kohdalla monipuolisempana romanikielen käyttönä. Useassa tapauksessa keskustelijat käyttävät romanikielisiä lauseita esitelläkseen romanikielen taitoaan ja siten vakuuttaakseen romaniuttaan, esimerkiksi toisen ilmaistessa epäilynsä tästä. Romanikielisen toivotuksen tai kehotuksen käyttöä esiintyy joillakin nimimerkeillä, jotka eivät muutoin käytä taivutettua romanikieltä. Romanikielen tuntemus muiden ryhmien parissa on yhä niin harvinaista, että romanikielisellä toivotuksella tai romanikieleen pohjautuvalla sanalla toivotuksessa rajataan toivotuksen vastaanottajat toisiin romaneihin. Toinen verkkokeskustelussa esiintyvä keino rajata toivomus keskustelupalstaa käyttäville romaneille on lisätä suomenkieliseen toivotukseen sana kaaleille.

\subsection{Suomenkielisissä lauseissa esiintyvien romanikielisten lekseemien sanaluokat}

Kuviosarjassa 1 esitetään nimimerkkien suo- menkielisissä lauseissa esiintyvien romanikielisten lekseemien sanaluokat. Näihin kuvioihin on sisällytetty myös substantiivi romani sen romanikielisen alkuperän vuoksi, vaikka sana onkin suomenkielinen. Sana romani ei vaikuta nimimerkkien väliseen vertailuun, koska se esiintyy jokaisella nimimerkillä.

Kuviosarjasta 1 huomaamme, että substantiivit ovat yleisimmin käytetty romanikielen sanaluokka jokaisen kirjoittajan suomenkielisissä lauseissa. Lisäksi puolet, viisi kymmenestä nimimerkistä, käyttää pelkkiä substantiiveja. Muiden nimimerkkien välillä on vaihtelua sanaluokkien käytössä, sillä I käyttää neljää, A ja F kolmea ja H kahta eri sanaluokkaa. Nimimerkki H:n lekseemeistä kaksi on romanikielisestä vakiintuneesta toivotuksesta, jota usea palstan kirjoittaja käyttää joko suomenkielisten tai romanikielisten viestien perässä. I ja E käyttävät substantiivi / adjektiivi -luokkaa, joka on käytännössä lekseemi jeero 'raukka, ressukka, raukkamainen'. E käyttää romanikielen kieliopin mukaan taivutettua sanaa jeer-es (raukka-OBL) ${ }^{7}$ adjektiivisessa merkityksessä 'raukka, parka, ressukka'. I käyttää kahdesti romanikielen nominatiivimuotoa jeero merkityksessä 'raukkamainen' ja kerran suomen taivutuksen mukaista muotoa jeero-ja-han (raukka-PL.PART-CLI) adjektiivisemmassa merkityksessä 'raukkojahan, ressukoitahan'.

\subsection{Romanikielisissä lauseissa esiintyvien romanikielisten lekseemien sanaluokat}

Tässä luvussa tarkastelen sanaluokkia, jotka esiintyvät kehyskieleltään suomenkielisten viestien romanikielisissä lauseissa.

Kuvioista huomataan, että C, D, E ja I käyttävät usean romanikielen sanaluokan sanoja romanikielisissä lauseissaan. Kun nimimerkit

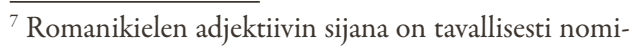
natiivi.
} 


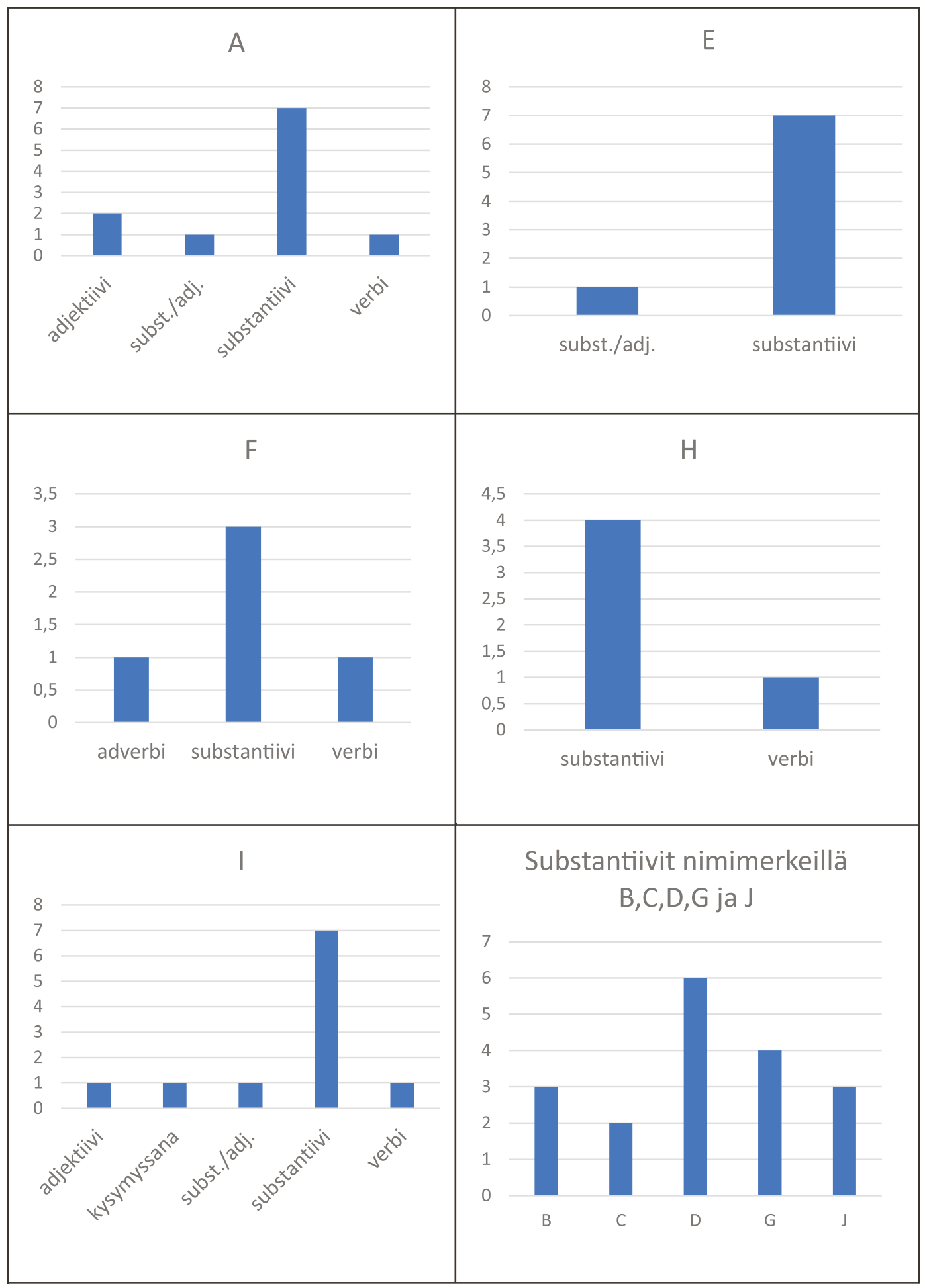

Kuviosarja 1. Romanikielen sanluokkien käyttö suomenkielisissä lauseissa nimimerkeillä (AJ). Kuvioissa vasemmassa reunassa oleva luku esittää kunkin sanaluokan sanojen määrän. Vain substantiiveja käyttävien nimimerkkien yhteistaulukko on viimeisessä ruudussa. 

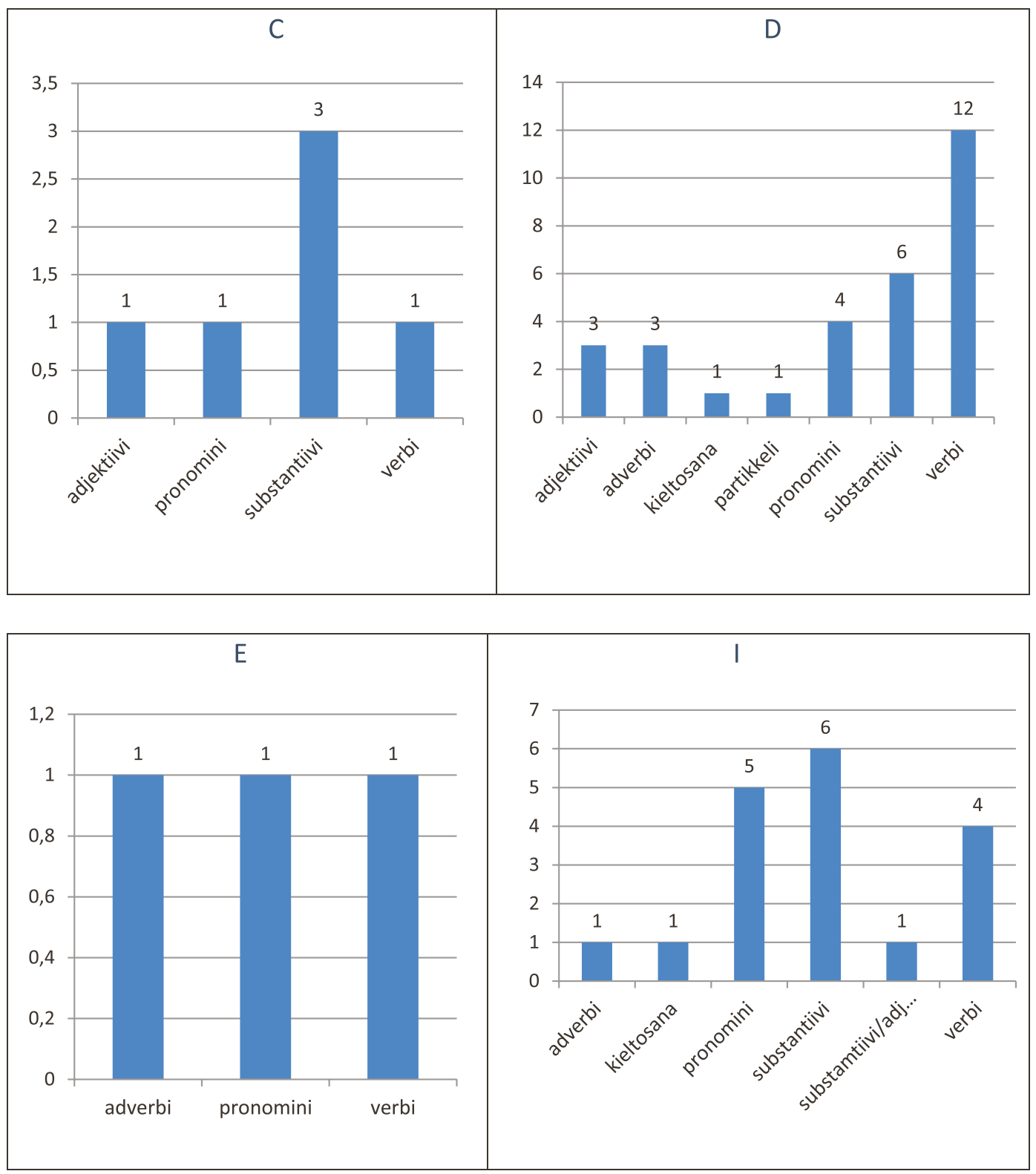

Kuviosarja 2. Romanikielen sanaluokat nimimerkkien C, D, E ja I romanikielisissä lauseissa.

C, D ja E käyttävät suomenkielisissä lauseissaan vain romanikielen substantiiveja, romanikielisissä lauseissaan C käyttää neljän, D seitsemän ja E kolmen eri sanaluokan sanoja. Ainoastaan I käyttää useiden eri romanikielen sanaluokkien sanoja sekä suomen- että romanikielisissä lauseissaan. I on kirjoittaja, joka leikittelee kahdella kielellä vastatessaan kirjoittajalle, jolla on tiedossaan vähemmän romanikielen sanoja. E käyttää romanikieltä huomioidessaan Suomen romanien häveliäisyyssäännöt seurusteluun liittyvän aiheen kohdalla (koodinvaihdosta häveliäisyyssääntöjen noudattamisessa ks. Granqvist \& Vil- 
janen, 2002; Kovanen, 2013a, 2013b; Salo, 2017). C ja I vaihtavat koodia romanikielelle osoittaen siten romaniuttaan. Useiden sanaluokkien käyttö viittaisi muita laajempaan ja luontevaan romanikielen käyttöön näillä kirjoittajilla.

Jokaisella vertailun nimimerkillä esiintyy vähintään kerran sana kaalo 'romani', tutkimusaineiston yleisin romanikielinen sana (vrt. Salo, 2017, s. 1, 6, 20). Romanikielisten lekseemien ja sanaluokkien käytön määrässä on selvä ero. A käyttää romanikieleen perustuvaa verbiä, kahta adjektiivia ja useampia substantiiveja, mutta ei käytä pitkien jaksojen koodinvaihtoa. F käyttää suomenkielisissä lauseissa kolmen eri sanaluokan romanikielisiä sanoja: adverbia, verbiä ja substantiiveja, vaikka romanikielisten sanojen märä onkin hänellä yhteensä vähäinen. Usea kirjoittaja käyttää suomenkielisissä lauseissa vain substantiiveja ja harvoja lekseemejä. Määrällisesti harvoja romanikielen lekseemejä on myös kirjoittajalla E, jolla on etnolektissään romanikielen kieliopillinen muoto ja kokonainen romanikielinen lause. Nimimerkki F on esimerkki kirjoittajasta, joka tuntee romanikielisiä sanoja ja ilmaisuja ja leikittelee kahden eri kielen sanoilla, vaikka ei kirjoita romanikielisiä lauseita.

\section{ROMANIKIELISTEN SANOJEN TAIVUTUS SUOMENKIELISISSÄ LAUSEISSA}

Tässä luvussa tarkastellaan romanikieleen pohjautuvien sanojen mukauttamista suomen morfologiaan. Useimmiten romanikieleen perustuvia sanoja taivutetaan aineistossa suomen kieliopin mukaan. Niiden taivutuksessa ei ole poikkeavia erityispiirteitä muihin suomeen mukautettuihin vierasperäisiin sanoihin verrattuna. Seuraava esimerkki (3a) esittää suomen kieliopin mukaan taivutetun romanikielen lekseemin suomenkielisessä lauseessa. Esimerkissä (3b) on myös romanikielen taivutuksen mukainen sanajeenov- $\boldsymbol{a}$ - $\boldsymbol{a}$, Kyseessä on preesensin yksikön 1. persoonan muoto. Keskustelija käyttää preesensin sanavartalon (džaan-/jaan- 'tietää, tuntea') sijasta vartaloa jeenov- ja taivuttaa yksikön 3. persoonamuodon yksikön ensimmäisessä persoonassa. Esimerkki (3c) antaa esimerkin sanan taivutuksesta romanikielen mukaan suomenkielisessä lauseessa.

(3)

(a) Jeero-j-a-han me ollaan loppujen lopuksikin... (I) raukka-PL-PART-CLI

(b) Verbin taivuttaminen romanikielen kieliopin mukaan ja substantiivin taivuttaminen suomen kieliopin mukaan.
Jeenov-a-a
joku kaale-i-sta
än ruotsalaisen? $(\mathrm{F})$ tuntea-PRS.1SG-IND romani-PL-ELA

(c.) Adjektiivin taivutus romanikielen obliikvisijassa: jeer-es Xseeivarmaan ees ymmärrä. (E) raukka-OBL 
Suurimmat yksilölliset erot taivutuksessa ovat yleensä sanojen romanikieleen pohjautuvassa osassa. Substantiivit kaalo ${ }^{8}$ ja kaajo ovat romanikielen yksikön nominatiiveja. Niiden taivutuksessa esiintyy vaihtelua kirjoittajien välillä ja myös nimimerkin sisäisesti. E käyttää yksikön genetiivin muotoa kaalo-n. Muoto kaal-ee tai kaaj-ee on romanikielen monikon näköinen, tosin pidentyneellä loppuvokaalilla, mutta monella kirjoittajalla se on käytössä yksiköllisenä, esimerkiksi I:1lä. ${ }^{9} \mathrm{~J}$ käyttää sanoista kaalo ja kaajo erityisen monia suomen kieliopin mukaan taivutettuja yhdyssanoja ja johdannaisia, joissa romanikieleen pohjautuvan sanan taivutus vaihtelee, kuten kaaj-e-is-tu-u ja kaal-ee-n-nainen ${ }^{10}$, mutta kaajo-n-miehen. J taivuttaa yksikkömuodon partitiivin kaal$\boldsymbol{e} \boldsymbol{e}$-ta, ei kaalo-a. H käyttää yksikkönä molempia muotoja kaalo ja kaal-ee. F ja J lisäävät monikon muodostukseensa perään suomen monikon tunnuksen - $t$ : kaal-ee-t ja kaaj-ee-t. Kaikkien romanikieleen pohjautuvien sanojen taivutuksen moninaisuutta suvaitaan aineistossa, ehdotuksia yhtenäistämiseen tai väitteitä oikeasta taivutustavasta ei esiinny. Näin on myös romanikielisten lauseiden kohdalla. Tämä aineistostani todettava ilmiö vastaa Mustanojan (2011, s. 25) havaintoa tutkimistaan yksilömurteista. Hänen mukaansa yksilön kielellinen resurssi (kielelliset mahdollisuudet) mahdollistaa puheessa esiintyvien elementtien persoonalliset kombinaatiot, mutta variaatio tapahtuu yhteisön sallimissa rajoissa. Kirjoittajien romanikieliset lauseet esiintyvät suomenkielisen kehyskielen sisällä.

Vain pieni osa vertailun nimimerkeis-

\footnotetext{
8 Saman näköinen adjektiivi kaalo merkitsee 'musta'. Adjektiivin taivutus on myös suomen kieliopin mukainen. Adjektiivi kaalo on tutkimusaineistossa paljon harvinaisempi kuin substantiivi kaalo. Ehkä sitä jopa vältetään sekaannuksen estämiseksi. Feminiinimuodon näköinen sana kaali on substantiivi ja merkitsee 'kahvi'. 9 Kumpikin muoto on yleinen aineistossa.

${ }^{10}$ Muotoa kaal-e, joka olisi romanikielessä monikko, käytetään tässä yksikön merkityksessä, ja $e$ on tässä pidentynyt.
}

tä käyttää romanikielen kieliopillisia ja lauseopillisia rakenteita. Keskimääräisesti tarkasteltuna nimimerkit, jotka kirjoittavat suomenkielisen keskustelun sisällä myös taivutetulla romanikielellä, käyttävät vertailun monipuolisinta romanikielen kielioppia ja sanastoa. Kahdella runsaimmin romanikielisiä lauseita kirjoittavalla nimimerkillä (D ja I) on myös runsaammin romanikielen sanaston ja taivutusmuotojen variointia muihin verrattuna. Muiden romanikielellä kirjoittavien nimimerkkien suomenkielisissä lauseissa ei ole kuitenkaan keskimääräisesti useampia romanikielen sanoja tai taivutusmuotoja kuin pelkästään suomenkielisiä lauseita kirjoittavilla.

Taivutetun romanikielen käyttö ei siten aina erotu suomenkielisten lauseiden kohdalla monipuolisempana romanikielen käyttönä. Yleisimpien yksittäisten sanojen kaalo ja kaajo taivutuksessa näkyy yksilöllisiä eroja. Ne ovat ilmeisesti näiden sanojen käyttötottumuksia eri kirjoittajilla. Romanikielisen toivotuksen tai kehotuksen käyttöä esiintyy joillakin nimimerkeillä, jotka eivät muutoin käytä taivutettua romanikieltä. Eri nimimerkit kirjoittavat samansisältöisen toivotuksen vaihtelevin kirjoitusasuin ja yksilöllisesti eroavin instrumentaalin muodostustavoin.

Kieliopillisten muotojen muodostamisessa on eroa sekä eri kirjoittajien välillä että samalla kirjoittajalla esimerkiksi romanikielisen ja suomenkielisen viestin osan välillä. Romanikielen taidosta kertoo selkeimmin romanikielellä kirjoittaminen ja romanikielen kieliopillisten muotojen hallinta. C, D, E ja I käyttävät koodinvaihtoa lauseiden ja virkkeiden sisällä. Heidän viesteissään on runsainta romanikielistä sanastoa ja eniten romanikielen eri taivutusmuotoja. Rikkainta variaatiota on nimimerkillä D. D on yksi niistä kirjoittajista, jotka kertovat asuvansa Ruotsissa. Aineistostani ilmenee, että romanikielen mukainen taivuttaminen on yhä osa elävää kielenkäyttöä. 


\section{ROMANIKIELISTEN JAKSOJEN DISKURSSITEHTÄVÄT}

Etnolektin käytöllä on jo sinänsä selkeä diskurssitehtävä. Suomen romanien etnolektillä ilmaistaan maamme kaale-vähemmistön ja sen Suomessa kehittyneen romanikulttuurin piiriin kuulumista. ${ }^{11}$ Kuten taulukoista 3 (liite 1) ja 4 (liite 2) huomattiin, jokaisella nimimerkeistä esiintyy etnolektissään etnisen identiteetin ilmaisua akselilla romani <> muu kuin romani. Tämän ilmaisemiseksi käytetään sanojajeeno,'mies' juuli, kaaji/kääji, kaajo, kaalo, sessi 'emäntä, ei-romaninainen' ja adjektiivi hortto 'aito, oikea' sen liittyessä

\footnotetext{
${ }^{11}$ Suomessa on omaleimainen romanikulttuuri, jota myös ainakin osa Ruotsiin muuttaneista Suomen romaneista noudattaa.
}

etnisyyttä merkitsevään sanaan.

Tässä luvussa tarkastelen lyhyesti romanien etnolektin ja romanikielen käytön sisäisiä, erilaisia diskurssitehtäviä yksilömurteiden kannalta. Taulukot 5 ja 6 esittävät kunkin nimimerkin käyttämät diskurssitehtävät. Olen analysoinut diskurssitehtävät sanojen merkitysten ja niiden laajemman kontekstin perusteella. Taulukon käsitteistä tarkoitan identiteetillä kirjoittajan tai vastaanottajan romani-identiteetin ilmaisemista romanikielisen elementin (esim. romanikielisen tai romanikieleen pohjautuvan sanan) avulla, puheenaiheella tarkoitan sitä, että kirjoittaja käyttää romanikielistä elementtiä puheenaiheen vuoksi, neutraalilla tarkoitan elementtiä, joka on romanikieltä, mutta sen käyttötarkoitus on luonteeltaan neutraali, lei-

Taulukko 5. Romanikielisten elementtien ja koodinvaihdon diskurssifunktiot vertailun nimimerkkien suomenkielisissä lauseissa.

\begin{tabular}{|l|l|l|}
\hline nimimerkki & käyttötarkoituskategoria & keskustelun aiheet \\
\hline A & $\begin{array}{l}\text { identiteetti } \\
\text { puheenaihe (häveliäisyys) } \\
\text { sanakäännös }\end{array}$ & $\begin{array}{l}\text { viesti toisille romaneille } \\
\text { sukupuolinen suuntaus, siveettömät tavat } \\
\text { romanikieiset sanat }\end{array}$ \\
\hline B & identiteetti & etnisyys \\
\hline C & identiteetti & etnisyys, oma ja toisen romanius \\
\hline D & identiteetti & oma romanius \\
\hline E & $\begin{array}{l}\text { identiteetti } \\
\text { neutraali }\end{array}$ & $\begin{array}{l}\text { etnisyys } \\
\text { lekseemi romani }\end{array}$ \\
\hline F & $\begin{array}{l}\text { identiteetti } \\
\text { leikittely }\end{array}$ & $\begin{array}{l}\text { etnisyys } \\
\text { romanikielen taito }\end{array}$ \\
\hline G & $\begin{array}{l}\text { identiteetti } \\
\text { neutraali }\end{array}$ & $\begin{array}{l}\text { etnisyys } \\
\text { lekseemi romani }\end{array}$ \\
\hline H & $\begin{array}{l}\text { identiteetti } \\
\text { neutraali }\end{array}$ & $\begin{array}{l}\text { etnisyys } \\
\text { lekseemi romani }\end{array}$ \\
\hline I & $\begin{array}{l}\text { identiteetti } \\
\text { leikittely (?) }\end{array}$ & $\begin{array}{l}\text { etnisyys } \\
\text { samanasuinen, mutta erimerkityksinen sana } \\
\text { suomessa ja romanikielessä } \\
\text { lekseemi romani }\end{array}$ \\
\hline neutraali & $\begin{array}{l}\text { romanius www-sivu, jossa romanikielinen } \\
\text { sana } \\
\text { musiikkiyhtyeen romanikielinen nimi }\end{array}$ \\
\hline J & $\begin{array}{l}\text { identiteetti } \\
\text { lainaus } \\
\text { puheenaihe }\end{array}$ & \\
\hline
\end{tabular}


kittelyllä romanikielisen elementin käyttöä sanaleikissä ja puheenaiheella tilannetta, jossa on käytettävä romanikielistä elementtiä puheenaiheen vuoksi, esimerkiksi mainittaessa romanikielinen erisnimi.

Romanikielisen haukkumasanan käyttö, kuten A:lla balihno'sika' kertoo romaniyhteisön sisäisestä kommunikoinnista. Nimimerkit A ja J käyttävät yksittäisten sanojen koodinvaihtoa häveliäisyyssyistä (vrt. Granqvist \& Viljanen, 2002; Kovanen, 2013a, 2013b; Salo, 2017, 2018). Romanikielisten elementtien muita diskurssitehtäviä ovat epäpuhtaan puheenaiheen merkitseminen, sanakäännös, neutraali funktio sekä leikittely kielitaidolla ja sanoilla (vrt. edellä). Neutraali funktio on romanikieleen perustuvalla suomenkielisellä lekseemillä romani, jolla osa nimimerkeistä ilmaisee etnisyyttä, ja sanalla boodoksen, jolla viitataan musiikkiyhtyeen nimeen. ${ }^{12}$ Luen lekseemin romani romanikieliseksi elementiksi diskurssitehtävien taulukkoon, koska silläkin on etnisyyttä ilmaiseva funktionsa. A ja J käyttävät romanikielistä jaksoa puheenaiheen vuoksi, kielenvaihdon toimiessa ikään kuin etäännytyskeinona keskusteltaes-

\footnotetext{
12 Tällainen on myös muoto horttokaalojen sen tarkoittaessa musiikkiyhtyeen nimeä. Sana horttokaalo on käytössä aineistossa myös romanikielisessä merkityksessä 'aito romani'. Musiikkiyhtyeen nimenä sanalla ei ole varsinaista romanikielistä funktiota, sillä se on osa yleissuomea. Sanan boodoksen olen ottanut sen vuoksi mukaan diskurssitehtävien tarkasteluun, että se on rajatummin vain romanien tuntema sana jopa osana yhtyeen nimeä.
}

sa vältettävästä tai häveliäisyyttä vaativasta puheenaiheesta (vrt. Granqvist \& Viljanen 2002; Kovanen 2013a, 2013b; Salo, 2016, 2017). A:lla tällainen funktio on adjektiivilla ajasaavo 'sellainen', jolla vältetään sanan 'homoseksuaali' käyttö, lupni 'huora' ja 'lupnata' 'toimia prostituoituna'. Kaikki A:n ja B:n romanikieliset jaksot ovat yhden sanan pituisia. F käyttää romanikielistä sanaa ja kahden kielen sanaston taitoaan myös kielelliseen leikittelyyn, näin mahdollisesti myös nimimerkki I.

Kuten taulukot havainnollistavat, sekä suomenkielisissä että romanikielisissä lauseissa yleisin diskurssifunktio romanikielisille sanoille on etnisen identiteetin ilmaisu (kielen suhteesta identiteettiin vrt. Lappalainen, 2009, 619; viitaten De Fina ym., 2006; Eckert, 2000; Omoniyi \& White, 2006, ja identiteetin ilmaisuun vrt. esim. Priiki, 2017, s. 19). Jo romanikielisen elementin käyttö sinänsä manifestoi yleensä kirjoittajan romaniutta. E:n romanikielinen lause edustaa Suomen romanien häveliäisyyteen kuuluvaa kulttuuria ja samalla luonnollisesti myös kulttuurista romani-identiteettiä.

Esittelen seuraavaksi romanikielisten elementtien diskurssitehtäviä esimerkkilauseissa. Esimerkissä (4) käytetään romanikieltä osana toisen keskustelijan ojentamista. Romanikielisen deskriptiivisanan balibno käytöllä osoitetaan, että viesti tulee toiselta romanilta.

Taulukko 6. Romanikielen käytön diskurssifunktiot nimimerkkien romanikielisissä lauseissa.

\begin{tabular}{|l|l|l|}
\hline nimimerkki & käyttökategoria & keskustelun aiheet \\
\hline C & identiteetti & etnisyys, käsitykset romanikulttuurista \\
\hline D & identiteetti & etnisyys \\
\hline E & häveliäisyys, identiteetti & $\begin{array}{l}\text { Suomen romanien häveliäisyyssääntöjen } \\
\text { noudattaminen }\end{array}$ \\
\hline I & identiteetti & etnisyys, romanikulttuuri \\
\hline
\end{tabular}


(4) saattaa olla vaikka sun sukulaine mites sitte suu pannaan!

byi balibno mitä opetat täälä. (A)

sika

Lauseet (5a-b) ovat esimerkkejä epäpuhtaan puheenaiheen merkitsemisestä. Esimerkissä (5a) merkitään sukupuolikäyttäytymistä ilmaiseva sana, jossa $a$ on suomen vaikutuk- sesta pidentynyt, ja esimerkissä (5b) sukupuolisuuntautumista ilmaiseva sana ja samalla ikään kuin kierretään ilmaisemalla se toisella kielellä kuin muu lause.

(5)

a. Mutta oon sitä mieltä että nää ketkä vetää hihaan sun muuta tahi

lupnaa-vat nii vaikka se ei... (A)

harjoittaa prostituutiota ${ }^{13}$-PRS.3PL

b. ...elkää hyvät ihmiset ei Suomelta mikää siunaus hävijä yltä mikäli tuosta

Haavistosta tulee presidentti. mitä sillä on väliä että se on ajasaavo. Ei olla

sellainen

kaal-ee-t niin nirsoja jos joku haluaa meille kerrankin hyvää... jos normaali romani-PL-PL

kääji haluaa byvää mustalaisille nii...jakun tämä kaajo haluais

ei-romaninainen ei-romani

vaikuttaa kaaleitten asioibin ja viijä niitä eteenpäin niin heti hyökätä̈n vastaan siks

että se on ajasaavo ... (A)

sellainen

${ }^{13}$ ro. verbi lubav-

Esimerkissä (6) nimimerkki I leikittelee kielitaidolla ja sanoilla. Romanikieleen pohjautuva sana hoha-nnu < ȟohav-'valehdella' muistuttaa suomenkielistä sanaa hokannu, joka olisi yleiskielellä ilmaisten 'tajunnut, ymmärtänyt'. I:n viestiä edeltää toisen kirjoittajan esittämä kysymys, jossa tiedustellaan sanan hohannu merkitystä. 
(6) - mitä tarkoittaa boha-nnu'14. - olisko se sit 'tajunnu'. en oikee enää muista, mut valehdella-2.PTCP

'buomannu' tai jotain sinne päin.

- hehehehe susta pitäis tulla mustalaiskielen opettaja, vai et oikee muista, et varmastikaa oo ikinä ees tieny että mitä tarkottaa toi oli liian hyvä aattelin jos et

boha-nnu mun äskellistä viestiä niin kirjotan varmuurenvuoks

valehdella-2.PTCP

taas, nauraaaaa. (I)

14 Verbin hohav- vartalon $v$ katoaa ja suomen 2. partisiipin eli NUT-partiisiipin $n$ kahdentuu tässä.

Esimerkissä (7a) taivutetulla romanikielellä aloittaminen sinänsä manifestoi kirjoittajan romaniutta. Esimerkissä (7b) omaa romaniutta tuodaan sen sijaan esiin väitteellä, että toinen keskustelija ei edusta kunnollista tai aitoa romaniutta. Kirjoittajan perusteita ovat etnisen romaniuden määrä ja hänen henkilökohtaiset käsityksensä ruokavalion ja uskonnollisten tapojen liittymisestä romaniuteen. Myös esimerkin (7c) diskurssitehtävä on oman romaniuden ilmaisu.

(7) a. Me sa-l-a

buut. Anna palaa nauraaaaa. (D)

minä nauraa-PRS.1/3SG-IND paljon

"Minä nauran paljon."

b. Kuule, olen enemmän mustalainen kuin sinä. Sinä olet puoli tai vartti romani, mutta minä olen koko kaalo. Vai joulu kinkkua. Joulu on pakanoiden jubla. En vietä joulua, romani

enkä syö sikaa.

tu aab-eh-a böpsikö. Siiv-en-ko kaaji(sessi) tu

sinä olla-PRS.2SG-IND höpsö ei-romani-PL-GEN ei-romaninainen sinä

aab-eb-a. (C)

olla-PRS-2SG-IND

Vapaa käännös: ”... Sinä olet höpsö. Et ole romani, olet valkolaisnainen.”

c. Tik tauvajeero X.Naa me aabh-a-a siva-nes-ko

katsoa-IMP tämä raukka NEG minä olla-PRS.1SG-IND ei-romani-SG-GEN

valpostsi. Maro phurniba h-in kaal-en-go komuj-en.

lapsi mitään. minun vanhuus olla-3PL.IND romani-OBL.PL-GEN ihminen-OBL.PL

Tu s-al jakke jeero jeenome phenn-a-a tuut.

sinä olla-2SG niin raukka mies minä sanoa-PRS.1SG-IND sinä-OBL

\footnotetext{
${ }^{15} \mathrm{C}$ muodosta genetiivimuodon monikon obliikvimuodosta -en- ja yksikön genetiivistä -ko.
} 
Aina ku et pysty oikeen mitään muuta vastaamaan niin otat kaal-een

romani-

kielen (puutteellisenkin) aseeks ja annat tulla täyeltä laialta. ... Tämäkään ei edusta sivistynyttä käytöstä mitä sulle tässä vastaan mutta sanon sen kuitenki sydämestäni koska ethän sä

taitamaton kentos bypi ihan miten sä haluut...

lapsi

... ilman että tarvii ketään mielistellä tai tinkiä kaaloud-esta-a. (I)

romanius-ELA-omistusliite

”Katso tuota raukkamaista miestä X:ää. En minä ole mikään valkolaisten kakara. Minun vanhempani ovat romaneja. Sinä olet niin raukkamainen mies, sanon sinulle. Aina kun et oikein pysty mitään muuta vastaamaan niin otat romanikielen... ethän sä taitamaton lapsi hypi miten haluut... tai tinkiä romaniudestaan"

Esimerkit (6-7) vastaavat havaintoja keskustelijan oman ja muiden tilanteeseen osallistuvien identiteetin konstruoinnista kielellisten valintojen avulla (Auer, 2007; Lappalainen, 2009, s. 619). Keskustelun rakentuessa kirjoittajat ottavat käyttöön romanikielen tai viestiään vahvistavat romanikieliset sanat (vrt. Gumperz, 2001, s. 218-223).

Esimerkissä (8) romanikieltä käytetään kommentin yksityisluonteisimmassa osassa, joka on tarkoitettu tietylle romanikirjoittajalle. E:n romanikielinen osio on yksittäinen, lyhyt ja ehyt lause muutoin suomenkielisen viestin perässä.

(8) Eihän täällä foorumilla ole ollut kunnon keskustelua pitkiin aikoibin ja niimpä kehottaisinkin vaan rohkeastijatkamaan täällä. Kyllä aina päivänvalon kestäviä aibeita löytyy, niin minulta kuin muiltain. Me-ki abh-a-a kokares. (E) minä-CLIT olla-PRS.1SG-IND yksin

Romanikielen käytön nykyinen vähäisyys näkyy vertailuaineistossa kuten koko tutkimusaineistossakin ${ }^{16}$ sekä romanikielisten elementtien prosentuaalisessa osuudessa että aiheiltaan varsinaisesti monipuolisen romanikielisen keskustelun puutteena. Tämä osoittaa vertailtujen nimimerkkien edustavan hyvin koko keskustelupalstan aineistoa tästä näkökulmasta tarkasteltuna (vrt. Salo, 2017).

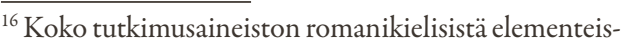
tä ja niiden käyttötarkoituksista on valmistunut Salon (2016) samanaikainen tutkimus. Projekti Suomen romanikieli ja muut Itämeren alueen romanikielen murteet puolestaan osoittaa tuloksissaan, että Suomessa löytyy yhä joitakuita romanikielen hyviä puhujia.
}

Romanikielisten elementtien käyttö suomenkielisissä lauseissa toimii enimmäkseen eri aiheista keskustelemisen keinona ja mahdollistajana. Niiden käytöllä on keskustelussa omia tehtäviään. Romanikielellä ilmaistaan erityisiä, keskustelun aiheeseen tarvittavia asioita. Sitä käytetään aineistossa melko rajatuista aihepiireistä, mutta se on käyttökelpoinen kieli erityistehtäviinsä (vrt. Salo, 2017; Hedman, 2004, 2009). Nimimerkki E:n henkilökohtainen viesti poikkeaa funktioltaan vertailun muista romanikielisistä lauseista. Nimimerkki F on esimerkki kirjoittajasta, joka tuntee romanikielisiä sanoja ja ilmaisuja ja leikittelee 
kahden eri kielen sanoilla, vaikka ei kirjoita romanikielisiä lauseita. Hän ilmaisee muista vertailun kirjoittajista poikkeavalla tavalla romanikielen tuntemustaan.

\section{KOKOAVAA TARKASTELUA}

Kukin vertailun nimimerkki vaikuttaa olevan pääkieleltään suomenkielinen, myös ne nimimerkeistä, jotka ilmoittavat asuvansa Ruotsissa. Romanikielisiä elementtejä käytetään suomenkielisissä lauseissa kuitenkin monenlaisissa tarkoituksissa. Kyseessä ei ole vain yleiseen käyttöön otettujen käännössanojen toistelu, vaan keskustelijat käyttävät sanoja tarkoituksenmukaisesti ja yksilöllisiin tarkoituksiin. Romanikielisiä sanoja esiintyy nimimerkeillä seuraavissa aihepiireissä ja tilanteissa:

- Kun osoitetaan kielen avulla, että viestit ovat tarkoitettuja romaneille. Tämä on yleisin käyttötarkoitus vertailtavilla nimimerkeillä. Tutkimukseni kirjoittajat käyttävät koodinvaihtoa ryhmäidentiteetin muodostajana ja etnisten ryhmien rajaajana sanallisessa vuorovaikutuksessa (vrt. Auer, 1998). Tutkimukseni osoittaa, että vertailun nimimerkeistä $A$, C, D ja F käyttävät romanikielisiä elementtejä aiheen ollessa keskustelijoiden romanius. C, E ja $\mathrm{F}$ erottavat niiden avulla vain romaneille ja myös pääväestölle osoitetut viestit toisistaan. A ja J käyttävät niitä, kun aiheena on keskustelijoiden suhde romanikulttuuriin, esimerkiksi sen tabuihin, joka liittyy välistä kiinteästi keskusteluun romaniudesta.

- Nimimerkit D, F ja I käyttävät romanikielisiä elementtejä muodostaessaan sanojen avulla kielellisiä leikkejä. Varsinkin I osoittaa sanaleikillä olevansa romanikielen taidossa parempi kuin edellinen keskustelija.

- Nimimerkit A, F, G, I ja J käyttävät romanikielisiä sanoja lainatessaan ja kääntäessään romanikieltä suomeksi.

Nämä käyttötarkoitukset limittyvät monelta osin toisiinsa. Tutkimukseni osoittaa, että romanikielisten elementtien käyttö suomenkielisissä lauseissa on tarkoituksellista ja valinnaista. Vertailun kirjoittajien kohdalla niiden käytössä ei näytä olevan kyse sekakielisyydestä, puutteellisesta suomen kielen taidosta tai suomenkielisten sanojen unohtamisesta ja korvaamisesta romanikielisillä. Sen sijaan kirjoittajan henkilökohtainen romanikielen taito näyttää vaikuttavan siihen, paljonko ja minkälaisia romanikielisiä elementtejä viesteissä on. Koodinvaihto on osa yhteisiä, kaikkien kirjoittajien tuntemia pelisääntöjä. Sen avulla voidaan keskustella romanikulttuurin mukaan soveliaasti ja samalla ilmaista henkilökohtaisia mielipiteitä, puhua sopimattomistakin aihepiireistä ja pysyä sopivuuden rajoissa solvatessa tiettyä keskustelijaa (Salo, 2016, 2017 passim; Kovanen, 2013a, passim; 2013 b, passim). Useimmiten romanikieliset lauseet ja sanat otetaan käyttöön haluttaessa ilmaista romani-identiteettiä. Keinot romani-identiteetin ilmaisemiseen eroavat yksilöllisesti. Kaikki Suomen romanikulttuurin puhtaus- ja häveliäisyyssääntöihin liittyvästä aiheesta keskustelevat nimimerkit käyttävät koodinvaihtoa, useimmiten yhden sanan mittaista. Näissä käyttötarkoituksissa esiintyy romanikieleen pohjautuvia adjektiiveja, substantiiveja ja verbejä. Nimimerkeistä kolme käyttää yhtä tai useampaa romanikielistä substantiivia tai adjektiivin luonteista substantiivia toista haukkuessaan tai moittiessaan.

\section{PÄÄTELMIÄ}

Nimimerkit oli valittu vertailuun viestien sisällön osalta sattumanvaraisesti, perusteena se, että nimimerkeillä on kirjoitettu useita viestejä, sekä se, että niistä löytyy vähintään yksi romanikielinen elementti (muu kuin sana romani). Romani on etnisyyttä ilmaiseva lekseemi, jota Suomen romanit eivät käytä keskustelun romanikielisissä jaksoissaan. Vaikkakin vertailun ulkopuolelle jäi useita 
kiinnostavia romanikielisiä sanoja suomenkielisissä lauseissa käyttäviä kirjoittajia, jo vertaillut nimimerkit toivat esiin eroja ja yksilöllisiä piirteitä romanikielisten sanojen käytössä eri kirjoittajilla. Tärkeimmät erojen mittarit ovat romanikielisten elementtien käytön määrä, käyttötehtävät ja käyttöyhteydet eli erilaiset keskustelutilanteet sekä kirjoitusasut ja taivutustavat. Jopa yleisimmän romanikielisen sanan käytössä esiintyy sekä yksikkömuodon että monikkomuodon käyttöä yksikön merkityksessä. Vaihtelua yksikön 1. persoonan ja yksikön 3. persoonan muotojen välillä yksikön 1. persoonan merkityksessä esiintyy myös. Romanikielisten sanojen kirjoitusasussa ja kieliopillisessa taivutuksessa esiintyy yksilöllisiä eroja, samoin romanikieleen pohjautuvien sanojen suomenkielisessä taivutuksessa niiden romanikielisen osan kohdalla. Nimimerkki D on tässä vertailuaineistossa ainoa, joka taivuttaa suomenkielisessä lauseessa sanan nominatiivimuodon eri sijassa kuin romanikielisessä lauseessa (jossa hän käyttää yksikön obliikvimuotoa / monikon nominatiivia). Aineistoni kirjoitetussa tekstissä erottuvat yksilömurteet ovat todennäköisesti pikemminkin kirjoittajien lähiryhmän murteita, perheiden ja niiden romanien, joiden kanssa he yleensä käyttävät puheessaan romanikielisiä ilmaisuja.

Yleisimmät kirjoittajien käyttämät lekseemit ilmaisevat etnisyyttä akselilla romani <> muu kuin romani, jotka ovat yleisimpiä lekseemejä myös koko aineiston tarkastelussa. Romanikielinen sanasto on keskenään vaihtelevampaa niillä nimimerkeillä, joilla se on runsaampaa. Sanaston laatu ja määrä johtuvat osaltaan siitä, mistä puheenaiheista nimimerkit käyvät keskustelua: onko aiheena henkilökohtainen yksinäisyys, oma romanikulttuurin tuntemus ja romanius ilmaistuna iloiseen tai riitaisaan sävyyn, toisen kirjoittajan tai muun henkilön moittiminen, leikittely kahden kielen sanoilla vai uskontoon liittyvä tai muutoin ystävällinen toivotus. Suomenkielisissä lauseissa käytetään romanikielisistä sanoista eniten substantiiveja. Eri sanaluokkien käyttö vastaa tässä tarkastelussa paljolti koko aineiston kokonaiskuvaa, samoin käytettyjen lekseemien etymologia. Suomen romanien verkkokeskustelun kielessä ovat säilyneet erityisesti monet varhaista intialaista alkuperää olevat lekseemit. Tämä on nähtävissä myös yksilömurteiden tarkastelussa. Tässä aineistossa esiintyy myös yksi harvalukuisista suomesta lainatuista romanikielen sanoista, höpsiko 'höpsö'.

Käyttötehtävät ja tilanteet, kuten keskustelukumppanin vaihdos, ovat tekijöitä, joiden avulla voi tarkastella romanikielen käytön merkityksiä eri osallistujilla. Aineistosta erottuu erilaisia puhujaprofiileja, jotka kertovat romanikielen tilasta ja tehtävistä romanivähemmistön verkkokeskustelussa. Vähemmistökielen puhujien kielenvaihto dominoivammalle kielelle on yleistä ympäristössä, jossa virallinen kieli on toinen, varsinaisella kouluajalla tapahtuva, opetussuunnitelmaan kuuluva kielenopetus koskee muita kieliä ja omaa kieltä käytetään vähenevässä määrin lähinnä oman vähemmistön parissa. Romanioppilaiden osuus samassa koulussa ja samalla luokalla on Suomessa yleensä ollut pieni, usein jopa vain yksi romanioppilas luokalla, ja romanikielen opetus on harvinaista, vapaaehtoista ja varsinaisen kouluajan ulkopuolella tapahtuvaa.

Suomen romanivähemmistön verkkokeskustelussa on selkeästi havaittavissa kielellisten valintojen yhteys keskustelijan oman ja toisten keskustelijoiden identiteetin osoittamiseen. Suomen romanien suomenkielisessä verkkokeskustelussa etnistä vähemmistöidentiteettiä vahvistetaan romanikielisten sanojen ja lauseiden avulla. Tutkimukseni on näin liitettävissä myös sosiolingvistiikan toisen aallon teorian vahvistukseksi. Tutkimusaineistoni keskustelijoiden parissa oma etninen vähemmistöidentiteetti, romanius, on myönteinen 
attribuutti. Vuorovaikutussosiolingvistiikan havainto myös muiden keskusteluun osallistuvien identiteetin konstruoinnista saa vahvistuksen näissä tilanteissa, joissa keskustelija ryhtyy käyttämään koodinvaihtoa romanikielelle joutuessaan todistamaan romaniuttaan ja useammassa tapauksessa myös todistellessaan toisen osapuolen vähemmän aitoa romaniutta. Romaniutta todistetaan verkkokeskustelussa kielen sekä kielellisten ja kulttuuristen sääntöjen käytön avulla (vrt. Kovanen 2013a, 2013b; Salo, 2016). Yksilölliset erot valittujen nimimerkkien romanikielisten elementtien käytössä ovat sanaston määrällisiä eroja, eroavaisuuksia romanikielen kieliopillisessa taivutuksessa ja siinä, käytetäänkö pitkiä romanikielisiä jaksoja, pelkästään vakiintuneita toivotuksia vai ainoastaan yksittäisiä sanoja, jopa vain yhtä romanikieleen pohjautuvaa, yleistä, suomen kieliopin mukaan taivutettua sanaa. Salon $(2016,2017)$ havainnot korpuksen koko aineistosta ovat samanlaiset. Nimimerkit edustavat siten aineiston tyypillisiä kirjoittajia romanikielisten elementtien käytössään. Romanikielen käyttötilanteet ja -tarkoitukset ovat vertailuni nimimerkeillä vain vähän toisistaan eroavia.

Kielen idiolektistuminen (vrt. esim. Kokko, 2007, s. 31-45) on havaittavissa aineistossani etenkin sanojen taivutuksessa. Kielen käytön yksilölliset erot voivat johtua joko oman lähipiirin kielen käytön vaikutuksesta tai oman muistin varassa olevasta kielitaidosta. Muiden kielten - Suomessa ennen kaikkea suomen, alueellisesti ruotsin ja nykyään myös englannin - dominoivuus aiheuttaa helposti vähemmistökielen käytön harvinaistumista ja kielen pirstoutumista ja idiolektistumista. Suomen romanikieli on ollut historiallisesti ja koko ajan enenevästi dominoivien kielten paineessa. Aineistoni kirjoittajilla romanikielinen taivutus on vähäisempää kuin suomenkielinen ja se vaihtelee eri kirjoittajilla. Ilmeisesti tieto taivutuksesta on heikentynyt, kuten Hedma- nin (2009) tutkimuksesta ilmenee. Esimerkkinä tästä on romanikieltä osaavien E:n ja D:n obliikvimuodon käyttö nominatiivin sijasta tai monikkomuodon käyttö yksikön sijasta. D käyttää tällaista muotoa (jujja) romanikielisessä lauseessa, mutta yksikkömuotoa (juuli) suomenkielisessä. Näitä voi luonnehtia hyperkorrekteiksi muodoiksi. Romanikielisten sanojen kirjoitusasujen kohdalla vaihtelulle on osin historialliset syyt; alueelliset erot sanojen äänne- ja kirjoitusasussa ovat perinteisiä, kuten yleensäkin murteissa, eikä romanikieleen ole kehitetty varsinaista standardia. Tutkimusaiheeni on herättänyt mielenkiintoni vielä uusiin näkökulmiin, romanikielen yksilömurteiden tutkimusta voisi kohdistaa myös siihen, esiintyykö eri suomen murteita puhuvilla romaneilla keskenään erilaista romanikielen käyttöä, vaikkakaan siihen viittaavaa ei ole tullut tämänhetkisessä tutkimusaineistossani varsinaisesti esiin.

\begin{tabular}{|l|}
\hline Lyhenteet \\
\hline ABL $=$ ablatiivi \\
\hline ADV $=$ adverbi \\
\hline CLI = liitepartikkeli \\
\hline DAT = datiivi \\
\hline ELA = elatiivi \\
\hline F $=$ feminiini \\
\hline GEN = genetiivi \\
\hline IND = indikatiivi \\
\hline IMP $=$ imperatiivi \\
\hline $\mathrm{M}=$ maskuliini \\
\hline NEG $=$ negaatio \\
\hline NOM = nominatiivi \\
\hline OBL = obliikvi \\
\hline PART = partitiivi \\
\hline PL = monikko \\
\hline PRS = preesens \\
\hline PTCP = partisiippi \\
\hline SG = yksikkö \\
\hline
\end{tabular}




\section{LÄHTEET}

Adamou, E. \& Granqvist, K. (2015). Unevenly mixed Romani languages. International Journal of Bilingualism, 19 (5), 525-547.

Androutsopoulos, J. (2006). Introduction: sociolinguistics and computer-mediated communication. Journal of Sociolinguistics, 10 (4), 419-438.

Androutsopoulos, J. (2013). Code-switching in computer-mediated communication. Teoksessa S. C. Herring, D. Stein \& T. Virtanen (toim.), Pragmatics of computer-mediated communication, (s. 667-694). Berlin: De Gruyter Mouton.

Auer, P. (toim.) (1998). Code-switching in conversation: Language, interaction and identity. London/New York: Routledge.

Auer, P. (toim.) (2007). Style and social identities: alternative approaches to linguistic heterogeneity. Berlin: De Gruyter Mouton.

De Fina, A., Schiffrin, D. \& Bamberg, M. (toim.) (2006). Discourse and identity. Cambridge: Cambridge University Press.

Eckert, P. (2000). Linguistic variation as social practice: The linguistic construction of identity in Belten High. Oxford: Blackwell.

Eckert, P. (2012). Three waves of variation study: the emergence of meaning in the study of sociolinguistic variation. Annual Review of Anthropology, 41, 87-100.

Special Eurobarometer 386 - Europeans and their languages 2012. http://ec.europa.eu/ commfrontoffice/publicopinion/archives/ebs/ ebs 386 en.pdf.

Granqvist, K. (2000). Intrasentential codeswitching in the speech of Finnish Roma. A case study. Haettu 15.10.2018 osoitteesta http:// www.academia.edu/1723106/Intrasentential_Codeswitching_in_the_Speech_of_Finnish_Roma._A_Case_Study.

Granqvist, K. (2007). Suomen romanin äänne-ja muotorakenne. Suomen Itämaisen Seuran suomenkielisiä julkaisuja 36. Kotimaisten kielten tutkimuskeskuksen julkaisuja 145. Helsinki: Suomen Itämainen Seura ja Kotimaisten kielten tutkimuskeskus.

Granqvist, K. (2012). Metaphors of the Finnish Roma in Finnish and Romani. Teoksessa A. Idström \& E. Piirainen (toim.), Endangered Metaphors, (s. 293-314). Cognitive Linguistic
Studies in Cultural Contexts 2. Amsterdam/ Philadelphia: John Benjamins.

Granqvist, K. (2013). Romanikielen taidon heikkeneminen ja pararomani. Teoksessa K. Granqvist \& M. Salo (toim.), Romanikieli ja sen tutkimusalat, (s. 164-194). Helsinki: Suomalaisen Kirjallisuuden Seura.

Granqvist, K. \& Pirttisaari, H. (2003). Suomen romanin leksikaalisista kerrostumista ja niiden fonologisista ja morfologisista prosesseista. Puhe ja kieli, 23, 25-41.

Granqvist, K. \& Viljanen, A. M. (2002). Kielelliset tabut romanien puheessa. Teoksessa $S$. Laihiala-Kankainen, S. Pietikäinen \& H. Dufva (toim.), Moniääninen Suomi, (s. 109-125). Jyväskylä: Jyväskylän yliopisto, Soveltavan kielentutkimuksen keskus.

Gumperz, J. (1992). Contextualization and understanding. Teoksessa A. Duranti \& C. Goodwin (toim.), Rethinking context: language as an interactive phenomenon, (s. 229-252). Cambridge: Cambridge University Press.

Gumperz,J. (2001). Interactional sociolinguistics: a personal perspective. Teoksessa D. Schriffin, D. Tannen \& H. Hamilton (toim.), The handbook of discourse analysis, (s. 215-228). Oxford: Blackwell.

Haakana, M. (1999). Laughing matters: a conversation analytical study of laughter in doctorpatient interaction. Väitöskirja. Helsingin yliopisto.

Hedman, H. (2004). Suomen romanikieli salakielenä. Teoksessa M. Nenonen (toim.), Papers from the 30th Finnish Conference of Linguistics: Joensuu, May 15-16, 2003, (s. 42-48). Joensuu: University of Joensuu.

Hedman, H. (2009). Suomen romanikieli: sen asemaybteisössään, käyttö ja romanien kieliasenteet. Kotimaisten kielten tutkimuskeskuksen verkkojulkaisuja 8. Haettu 10.7.2017 osoitteesta http://scripta.kotus.fi/www/verkkojulkaisut/ julk8/.

Karppinen, J. (2011). Puhekielisyys verkkokeskustelussa. Pro gradu- tutkimus. Aalto-yliopiston kauppakorkeakoulu.

Koivisto, V. (1994). Romano-finitiko-angliko laavesko liin: romani-suomi-englanti-sanakirja: Romany-Finnish-English dictionary. Kotimaisten kielten tutkimuskeskuksen julkaisuja 74. Helsinki: Painatuskeskus. 
Koivisto, V. (2001). Suomi-romani-sanakirja: finitiko-romano laavesko liin. Suomalaisen Kirjallisuuden Seuran toimituksia 811. Kotimaisten kielten tutkimuskeskuksen julkaisuja 117. Helsinki: Suomalaisen Kirjallisuuden Seura ja Kotimaisten kielten tutkimuskeskus.

Kokko, O. (2007a). Inkerinsuomen pirstaleisuus: eräiden sijojen kehitys murteen yksilöllistymisen kuvastajana. Joensuun yliopiston humanistisia julkaisuja 48. Joensuu: Joensuun yliopisto.

Kokko, O. (2007b). Puheyhteisön hajoaminen ja inkerinsuomen nykytila. Väitöksenalkajaisesitelmä Joensuun yliopistossa 20. lokakuuta 2007. Haettu 9.1.2019 osoitteesta http://www. kotikielenseura.fi/virittaja/hakemistot/jutut/ kokko4_2007.pdf.

Kovanen, P. (2013a). Metakieltä vai kielitaidon paikkausta - koodinvaihtelu Suomen romanikielessä. Teoksessa K. Granqvist \& P. Rainò (toim.), Rapautuva kieli: kirjoituksia vähemmistökielten kulumisesta ja kadosta, (s. 173-207). Suomalaisen Kirjallisuuden Seuran toimituksia 1404. Helsinki: Suomalaisen Kirjallisuuden Seura.

Kovanen, P. (2013b). Koodinvaihtelu romanikielessä. Teoksessa K. Granqvist ja M. Salo (toim.), Romanikieli ja sen tutkimusalat, (s. 195-216). Suomalaisen Kirjallisuuden Seuran toimituksia 1268. Helsinki: Suomalaisen Kirjallisuuden Seura.

Labov, W. (1972). Sociolinguistic patterns. Philadelphia: University of Pennsylvania Press.

Laiti, M. (2008). Romanikulttuuri. Teoksessa P. Brusila (toim.), Seksuaalisuus eri kulttuureissa, (s. 156-163). Helsinki: Duodecim.

Lappalainen, H. (2009). Tyylikästä identiteettitutkimusta. Virittäjä, 113, 619-626.

Matras, Y. (2009). Language contact. Cambridge: Cambridge University Press.

Mustanoja, L. (2011). Idiolekti ja sen muuttuminen: reaaliaikatutkimus Tampereen pubekielestä. Acta Universitatis Tamperensis 1605. Tampere: Tampere University Press.

Nahkola, K. \& Saanilahti, M. (2001). Kymmenen vuotta myöhemmin: seuruututkimus kielenmuutosten etenemisestä yksilön kielessä ja pubeyhteisössä. Turun yliopiston suomalaisen ja yleisen kielitieteen laitoksen julkaisuja 68. Turku: Turun yliopisto.

Nuolijärvi, P. (1986). Kieliyhteisön vaihto ja muut- tajan identiteetti. Tietolipas 100. Helsinki: Suomalaisen Kirjallisuuden Seura.

Nuolijärvi, P. (2006). Helsingin kieliolot 2000-luvun alussa. Teoksessa K. Juusela \& K. Nisula (toim.), Helsinki kieliyhteisönä, (s. 318-335). Helsinki: Helsingin yliopisto.

Nuolijärvi, P. \& Sorjonen, M.-L. (2005). Miten kuvata muutosta? Pubutun kielen tutkimuksen lähtökohtia murteenseuruubankkeen pohjalta. Kotimaisten kielten tutkimuskeskuksen verkkojulkaisuja 13. Haettu 1.10.2018 osoitteesta http://scripta.kotus.fi/www/verkkojulkaisut/ julk13/miten_kuvata_muutosta_verkkojulkaisu_13.pdf.

Omoniyi, T. \& White, G. (toim.) (2006). The sociolinguistics of identity. London/New York: Continuum.

Palander, M. (1996). Vaibtelu Savonlinnan seudun välimurteissa. Suomalaisen Kirjallisuuden Seuran toimituksia 648. Helsinki: Suomalaisen Kirjallisuuden Seura.

Paunonen, H. (2005). Helsinkiläisiä puhujaprofileja. Virittäjä 2/2005, s. 162-200.

Pirttisaari, H. (2003). Muutos ja variaatio Suomen romanin verbien taivutustyypeissä. Virittäjä, 107, 508-528.

Pirttisaari, H. (2004). Contact-induced changes in Finnish Romani: passive voice. Haettu 1.1.2018 osoitteesta http://www.ling.helsinki.fi/uhlcs/ LENCA/LENCA-2/information/datei/29pirttisaari.pdf.

Priiki, K. (2017). Hän, se, tää vai toi? Vuorovaikutussosiolingvistinen tutkimus henkilöviittauksista Kaakkois-Satakunnan nykypuhekielessä. Annales Universitatis Turkuensis C 432. Turku: Turun yliopisto.

Routarinne, S. (2003). Tytöt äänessä: parenteesit ja nouseva sävelkulku kertojan vuorovaikutuskeinoina. Helsinki: Suomalaisen Kirjallisuuden Seura.

Sacks, H. (1992). Lectures on conversation 1-2. Oxford: Blackwell.

Salo, M. (2015). Suomen romanien omaleimainen kieli Internet-keskustelussa.Idäntutkimus, 22 (3), 56-58.

Salo, M. (2016). Romanikielisten lainasanojen ja koodinvaihdon tehtävät Suomen romanien suomenkielisessä verkkokeskustelussa. Puhe ja kieli, 36), 251-271.

Salo, M. (2017). Romanikielinen ja romanikie- 
leen pohjautuva kieliaines Suomen romanien suomenkielisessä verkkokeskustelussa.Virittäjä, 121, 534-566.

Schegloff, E. (1995). Discourse as an interactional achievement III: The omnirelevance of action. Research on Language and Social Interaction, 28, 185-211.

Seppänen, E.-L. (1998). Läsnäolon pronominit: tämä, tuo, seja hän viittaamassa keskustelun osallistujaan. Helsinki: Suomalaisen Kirjallisuuden Seura.

Sidnell, J. \& Stivers, T. (toim.) (2012). The handbook of conversation analysis. Chichester: WileyBlackwell.

Vaattovaara, J. (2009). Meän tapa pubua: Tornionlaakso pellolaisnuorten subjektiivisena paikkana ja murrealueena. Helsinki: Suomalaisen Kirjal- lisuuden Seura.

Viljanen, A. M. (2013). "Sillonhan se on automaattisesti lakki silmille pantava": romanit vielä hiljaisemmat suomalaiset. Teoksessa $\mathrm{K}$. Granqvist \& M. Salo (toim.), Romanikieli ja sen tutkimusalat, (s. 195-216). Helsinki: Suomalaisen Kirjallisuuden Seura.

Vuorela, K. \& Borin, L. (1998). Finnish Romani. Teoksessa S. Mac Mathúna \& A. Ó Corráin (toim.), Minority languages in Scandinavia, Britain and Ireland, (s. 51-76). Uppsala: Uppsala Universitet.

Åkerlund, A. (2004). Romaninuorten kieli Suomessa. Teoksessa M. Nenonen (toim.), Papers from the 30th Finnish Conference of Linguistics: Joensuu, May 15-16, 2003, (s. 237-239). Joensuu: University of Joensuu. 
LIITE 1.

Taulukko 3. Romanikieliset ja romanikieleen pohjautuvat sanat ja niiden määrät nimimerkkien suomenkielisissä lauseissa.

\begin{tabular}{|c|c|c|c|c|c|c|c|c|c|c|}
\hline \multirow[t]{2}{*}{ lekseemi/sanajuuri } & \multicolumn{10}{|c|}{ nimimerkki } \\
\hline & A & B & C & D & $\mathbf{E}$ & $\mathbf{F}$ & $\mathbf{G}$ & $\mathrm{H}$ & I & J \\
\hline aahh- / aaȟȟh 'olla' & & & 3 & & & & & 2 & 1 & \\
\hline ajasaavo 'sellainen' & 2 & & & & & & & & & \\
\hline baal 'hius, tukka' & 1 & & & & & & & & & \\
\hline $\begin{array}{l}\text { balihni/balihno 'sika } \\
\text { F/M' }\end{array}$ & 2 & & & & & & & & & \\
\hline boodos 'sanoma' & & & & & & & 1 & & 2 & \\
\hline daad/taad 'isä' & & & & 1 & & & & & & \\
\hline deevel/teevel 'jumala' & & & 1 & & 1 & & & 2 & & \\
\hline $\begin{array}{l}\text { deulikaano/teulikaano } \\
\text { 'uskovainen' }\end{array}$ & & & & & & & & & 1 & \\
\hline džaan-/jaan- 'tietää' & & & & & & 1 & & & & \\
\hline finitiko 'suomalainen' & & & & & & & & & 1 & \\
\hline freidiba 'vapaus' & & & & & & & & & 2 & \\
\hline hava interjektio & & & & & & 1 & & & & \\
\hline ȟohav. 'valehdella' & & & & & & 1 & & & & \\
\hline $\begin{array}{l}\text { hohiposkeero } \\
\text { 'valehtelija' }\end{array}$ & & & & 1 & & & & & & \\
\hline hortto 'aito, oikea' & 1 & & & & 2 & & 1 & & 3 & \\
\hline höpsikö 'höpsö' & & & 1 & & & & & & & \\
\hline $\begin{array}{l}\text { jeero/jeero + johdos } \\
\text { 'raukka, raukkamainen' }\end{array}$ & & & & & 1 & & & & 1 & \\
\hline juuli ‘romaninainen’ & & & & 2 & & & & & & \\
\hline $\begin{array}{l}\text { kaaji/kääji ‘ei- } \\
\text { romaninainen' }\end{array}$ & 5 & & 1 & & 1 & & & & & 1 \\
\hline $\begin{array}{l}\text { kaajo/kaavo, kaajo + } \\
\text { johdos 'ei-romani }\end{array}$ & 18 & & 2 & 19 & 29 & 8 & 8 & 4 & 34 & 30 \\
\hline $\begin{array}{l}\text { kaalo/ kaalo + johdos/ } \\
\text { kaalo + su.sana 'romani' }\end{array}$ & 28 & 14 & 3 & 35 & 56 & 8 & 11 & 15 & 130 & 32 \\
\hline kentos 'Iapsi' & & & & & & & & & 1 & \\
\hline latz < latšo 'kiltti' & & & & & & & & & 1 & \\
\hline $\begin{array}{l}\text { lupnata < lupnav- } \\
\text { 'huorata' }\end{array}$ & 1 & & & & & & & & & \\
\hline lupni 'huora' & 2 & & & & & & & & & \\
\hline minhu 'naisen sukuelin' & & & & & & & & & & 1 \\
\hline nikki (?) ${ }^{1}$ 'pois' & & & & & & & & & $(1)$ & \\
\hline phaal 'veli' & 1 & & & & & & & & & \\
\hline raklo 'ei-romanipoika' & & & & & 1 & & & & & \\
\hline romano 'romani' & & & & & & & & & 1 & \\
\hline
\end{tabular}




\begin{tabular}{|c|c|c|c|c|c|c|c|c|c|c|}
\hline \multirow[t]{2}{*}{ lekseemi/sanajuuri } & \multicolumn{10}{|c|}{ nimimerkki } \\
\hline & A & B & C & D & $E$ & $\mathbf{F}$ & G & $\mathbf{H}$ & I & $\mathbf{J}$ \\
\hline $\begin{array}{l}\text { sessi 'emäntä, ei- } \\
\text { romaninainen' }\end{array}$ & & & 1 & & & & & & & \\
\hline siiva 'ei-romaninainen' & 1 & & 1 & & & & & & & \\
\hline soske 'miksi' & & & & & & & & & 1 & \\
\hline terno 'nuori' & & & & & & & & & & 1 \\
\hline tu 'sinä' & & & 2 & & & & & & & \\
\hline
\end{tabular}

\footnotetext{
${ }^{1}$ Kysymysmerkki lekseemin nikki perässä on siksi, että kirjoittaja saattaa tarkoittaa joko romanikielistä sanaa merkitykseltään 'pois' tai suomenkielistä lyhennettä sanasta 'nimimerkki'.
} 
LIITE 2.

Taulukko 4. Romanikielisten lekseemien käyttömäärät suluissa ja taivutusmuodot nimimerkkien C, D, E ja I romanikielisissä lauseissa

\begin{tabular}{|c|c|c|c|c|}
\hline lekseemi & C & D & $E$ & I \\
\hline $\begin{array}{l}\text { aahh. / ahh- } \\
\text { 'olla' }\end{array}$ & $\begin{array}{l}\text { aah-e-ha } \\
\text {-olla-PRS.2.SG- } \\
\text { IND } \\
(2)\end{array}$ & $\begin{array}{l}\text { aahh-a-a/ } \\
\text { ahh-a-a olla- } \\
\text { PRS.1SG-IND } \\
\text { (2) }\end{array}$ & $\begin{array}{l}\text { aahh-a-a olla- } \\
\text { PRS.1SG-IND } \\
(1)\end{array}$ & $\begin{array}{l}\text { aahh-a-a } \\
\text { olla-PRS.1SG- } \\
\text { IND } \\
(1)\end{array}$ \\
\hline $\begin{array}{l}\text { ajasaavo } \\
\text { 'sellainen' }\end{array}$ & & $\begin{array}{l}\text { ajasaavo } \\
(1)\end{array}$ & & \\
\hline buut 'paljon' & & $\begin{array}{l}\text { buut } \\
(2)\end{array}$ & & \\
\hline $\begin{array}{l}\text { hajuv- 'tietää, } \\
\text { osata' }\end{array}$ & & $\begin{array}{l}\text { hajuv-a } \\
\text { tietää-PRS.1SG- } \\
\text { IND } \\
(1)\end{array}$ & & \\
\hline $\begin{array}{l}\text { hojume } \\
\text { 'vihainen' }\end{array}$ & & $\begin{array}{l}\text { hojume } \\
\text { (1) }\end{array}$ & & \\
\hline $\begin{array}{l}\text { hortto } \\
\text { aito, oikea' }\end{array}$ & & $\begin{array}{l}\text { hortta } \\
\text { (2) }\end{array}$ & & \\
\hline $\begin{array}{l}\text { höpsikö } \\
\text { 'höpsö' }\end{array}$ & $\begin{array}{l}\text { höpsikö } \\
\text { (1) }\end{array}$ & & & \\
\hline $\begin{array}{l}\text { jaan- 'tietää, } \\
\text { tuntea' }\end{array}$ & & $\begin{array}{l}\text { jaan-a-a } \\
\text { jaanav-a-a } \\
\text {-PRS.1SG.IND } \\
\text { jaan-es } \\
\text {-PRS.2SG.IND } \\
(5)\end{array}$ & & \\
\hline $\begin{array}{l}\text { jakke' / jakkes } \\
\text { 'niin' }\end{array}$ & & $\begin{array}{l}\text { jakke, jakkes } \\
(1)\end{array}$ & & $\begin{array}{l}\text { jakke } \\
(1)\end{array}$ \\
\hline $\begin{array}{l}\text { jeeno } \\
\text { 'mies,romanimies' }\end{array}$ & & & & $\begin{array}{l}\text { jeeno } \\
(1)\end{array}$ \\
\hline $\begin{array}{l}\text { jeero 'raukka, } \\
\text { raukkamainen' }\end{array}$ & & & & $\begin{array}{l}\text { jeero } \\
(2)\end{array}$ \\
\hline $\begin{array}{l}\text { juuli 'nainen, } \\
\text { romaninainen' }\end{array}$ & & $\begin{array}{l}\text { ju-j-ja } \\
\text {-välivok.-PL/ } \\
\text { SG.OBL } \\
\text { merkityksessä } \\
\text { SG.NOM } \\
(2)\end{array}$ & & \\
\hline $\begin{array}{l}\text { kaaji 'ei- } \\
\text { romaninainen' }\end{array}$ & $\begin{array}{l}\text { kääji } \\
(1)\end{array}$ & & & \\
\hline kaalo 'romani' & & $\begin{array}{l}\text { kaal-en-go } \\
\text {-PL.OBL-GEN } \\
\text { (2) }\end{array}$ & & (1) \\
\hline kaan 'nyt' & & $\begin{array}{l}\text { kaan } \\
(1)\end{array}$ & & \\
\hline
\end{tabular}




\begin{tabular}{|c|c|c|c|c|}
\hline lekseemi & C & D & $\mathbf{E}$ & I \\
\hline kokares 'yksin' & & & $\begin{array}{l}\text { kokares } \\
(1)\end{array}$ & \\
\hline komunis 'ihminen' & & & & $\begin{array}{l}\text { komuj-en -OBL. } \\
\text { PL } \\
\text { (1) }\end{array}$ \\
\hline maro 'minun' & & & & $\begin{array}{l}\text { maro } \\
(1)\end{array}$ \\
\hline me 'minä' & & $\begin{array}{l}\text { me } \\
(9)\end{array}$ & $\begin{array}{l}\text { me-ki } \\
\text { NOM+CLIT } \\
(1)\end{array}$ & $\begin{array}{l}\text { me } \\
(2)\end{array}$ \\
\hline mer 'kuolema' & & $\begin{array}{l}\text { merr } \\
(1)\end{array}$ & & \\
\hline naa 'ei' & & $\begin{array}{l}\text { naa } \\
(2)\end{array}$ & & $\begin{array}{l}\text { naa } \\
(1)\end{array}$ \\
\hline phenn- 'sanoa' & & $\begin{array}{l}\text { phenn-a } \\
\text {-PRS-1SG } \\
\text { merkityksessä } \\
3 S G \\
\text { phenn-el- } \\
\text { IND-3SG } \\
\text { merkityksessä } \\
\text { 2SG } \\
(2)\end{array}$ & & $\begin{array}{l}\text { phenn-a-a } \\
\text {-PRS-1SG-IND } \\
\text { (1) }\end{array}$ \\
\hline phurniba 'vanhuus' & & & & $\begin{array}{l}\text { phurniba NOM. } \\
\text { merkityksessä } \\
\text { 'vanhemmat' } \\
\text { (1) }\end{array}$ \\
\hline saaki 'asia' & & $\begin{array}{l}\text { saaki } \\
(1)\end{array}$ & & \\
\hline s-/h- 'olla' & & $\begin{array}{l}\text { S-an } \\
\text {-PRS.2PL.IND } \\
(2)\end{array}$ & & $\begin{array}{ll}\text { h-in } & \text {-PRS.3SG. } \\
\text { IND } & \\
\text { s-al } & \text {-PRS.2SG. } \\
\text { IND } & \\
(2) & \end{array}$ \\
\hline saa(v-) 'nauraa' & & $\begin{array}{l}\text { sa-I-a -PRS.3SG- } \\
\text { IND } \\
\text { merkityksessä } \\
\text {-PRS.1SG.IND } \\
\text { (4) }\end{array}$ & & \\
\hline satso 'tosi' & & $\begin{array}{l}\text { satso } \\
(1)\end{array}$ & & \\
\hline $\begin{array}{l}\text { sessi 'emäntä, ei- } \\
\text { romaninainen' }\end{array}$ & $\begin{array}{l}\text { sessi NOM. } \\
\text { (1) }\end{array}$ & & & \\
\hline
\end{tabular}




\begin{tabular}{|c|c|c|c|c|}
\hline lekseemi & C & D & $E$ & I \\
\hline sihkas 'hyvin' & & $\begin{array}{l}\text { sihkas ADV } \\
\text { (1) }\end{array}$ & & \\
\hline siivi 'ei-romani' F & & $\begin{array}{l}\text { siivi } \\
\text { (2) }\end{array}$ & & \\
\hline $\begin{array}{l}\text { siiva, siivo ei- } \\
\text { roman'i PL,SG.M }\end{array}$ & $\begin{array}{l}\text { siiv-en-ko-PL. } \\
\text { OBL-SG.GEN } \\
(1)\end{array}$ & (3) & & $\begin{array}{l}\text { siiv-(a-)nes-ko } \\
\text {-SG.OBL-GEN } \\
\text { (1) }\end{array}$ \\
\hline $\begin{array}{l}\text { so 'mitä, mikä, } \\
\text { joka' }\end{array}$ & & $\begin{array}{l}\text { so } \\
\text { (3) }\end{array}$ & & \\
\hline ta 'ja' & & $\begin{array}{l}\text { ta } \\
(3)\end{array}$ & & \\
\hline tauva 'tämä' & & & & $\begin{array}{l}\text { tauva } \\
(1)\end{array}$ \\
\hline tenkav- 'ajatella' & & $\begin{array}{l}\text { tenk-ill-a } \\
\text {-PRS.3SG-IND } \\
\text { merkityksessä } \\
\text {-PRS.2SG-IND } \\
(1)\end{array}$ & & \\
\hline $\begin{array}{l}\text { tikk- / dikk- 'nähdä, } \\
\text { katsoa' }\end{array}$ & & & & tik IMP (1) \\
\hline toola 'nuo' & & $\begin{array}{l}\text { toola } \\
\text { (2) }\end{array}$ & & \\
\hline touva 'tuo' & & $\begin{array}{l}\text { touva } \\
(3)\end{array}$ & & \\
\hline tsi 'jotain, mitään' & & & & tsi (1) \\
\hline tu 'sinä' & $\begin{array}{l}\text { tu NOM } \\
\text { (2) }\end{array}$ & $\begin{array}{ll}\text { tu-ke } & \text {-DAT } \\
\text { tuu } & \text { NOM } \\
(2) & \end{array}$ & & $\begin{array}{l}\text { tu } \\
\text { tuut } \mathrm{OBL} \\
(2)\end{array}$ \\
\hline tumen 'te' & & tumen & & \\
\hline $\begin{array}{l}\text { valpos 'pentu, } \\
\text { lapsi' }\end{array}$ & & & & $\begin{array}{l}\text { valpos } \\
(1) \\
\end{array}$ \\
\hline v- tulla' & & $\begin{array}{l}\text { v-el-a } \\
\text {-PRS-3SG-IND } \\
(2)\end{array}$ & & \\
\hline
\end{tabular}




\section{INDIVIDUAL DIFFERENCES IN THE USE OF ROMANI WORDS IN FINNISH WEB- DISCUSSION}

Mirkka Salo, University of Helsinki

In this study, I compare the idiolectal language forms of ten nicknames in the discussion board Suomi24.fi-romano. When there is more variation in the writers' idiolects, it usually indicates less commonly shared knowledge of the language and its reduced use. The aim is also to find out which Romani elements are important and useful for different writers in this digital discussion forum. As my method, I use sociolinguistic variation analysis. I have collected all messages from the ten nicknames during the period of 22.2.2003 to 18.7.2013. The discussion board is the only forum of its kind in Internet for Finnish Roma. The main language of the forum is Finnish, but many writers use a variety of Finnish that includes Romani words, Romani based words, Romani structures and even sentences in inflected Romani language. I call these parts of Romani language as Romani elements. The variety of Finnish used by Roma can be defined as an ethnolect. I have chosen as my data the messages of ten nicknames who have written ten or more messages and use at least one Romani element in their Finnish. These writers have different profiles as to their written messages. The speaker profiles tell about the current situation of the knowledge of Romani language and about distinct functions of Romani language in Finnish conversation.

The findings show that although some of the writers use only few or only a single Romani element, and although every writer uses them notably less than Finnish elements, Romani elements have special functions in the web-discussion conducted in Finnish by the Finnish Roma. The use of the Romani elements is highly functional and brings special significance into the communication: the elements are used when the issues which are related to Romani culture are being discussed. The unifying feature in the use of the Romani elements between the writers is that these elements are used when no other language can replace them. That is because of the special meanings they carry. The differences between writers in the inflection of Romani words indicate attrition in the knowledge of Romani grammar. Although several nicknames use Romani words and Romani sentences for signaling that they are real Roma, there is no correction of other writers' Romani grammar. The idiolects vary mostly in the use of Romani vocabulary and the use of Romani grammar varies in terms of quality and quantity.

Keywords: ethnolect, Finnish, idiolect, Romani, variation, web-discussion 